\title{
A database and tool for boundary conditions for regional air quality modeling: description and evaluation
}

\author{
B. H. Henderson ${ }^{1}$, F. Akhtar ${ }^{2}$, H. O. T. Pye ${ }^{3}$, S. L. Napelenok ${ }^{3}$, and W. T. Hutzell ${ }^{3}$ \\ ${ }^{1}$ Environmental Engineering Sciences, University of Florida, Gainesville, FL, USA \\ ${ }^{2} \mathrm{CSC}$, Alexandria, VA, USA \\ ${ }^{3}$ Atmospheric Modeling and Analysis Division, US Environmental Protection Agency, Research Triangle Park, \\ NC, USA \\ Correspondence to: B. H. Henderson (barronh@ufl.edu)
}

Received: 25 July 2013 - Published in Geosci. Model Dev. Discuss.: 9 September 2013

Revised: 20 December 2013 - Accepted: 2 January 2014 - Published: 18 February 2014

\begin{abstract}
Transported air pollutants receive increasing attention as regulations tighten and global concentrations increase. The need to represent international transport in regional air quality assessments requires improved representation of boundary concentrations. Currently available observations are too sparse vertically to provide boundary information, particularly for ozone precursors, but global simulations can be used to generate spatially and temporally varying lateral boundary conditions (LBC). This study presents a public database of global simulations designed and evaluated for use as LBC for air quality models (AQMs). The database covers the contiguous United States (CONUS) for the years 2001-2010 and contains hourly varying concentrations of ozone, aerosols, and their precursors. The database is complemented by a tool for configuring the global results as inputs to regional scale models (e.g., Community Multiscale Air Quality or Comprehensive Air quality Model with extensions). This study also presents an example application based on the CONUS domain, which is evaluated against satellite retrieved ozone and carbon monoxide vertical profiles. The results show performance is largely within uncertainty estimates for ozone from the Ozone Monitoring Instrument and carbon monoxide from the Measurements Of Pollution In The Troposphere (MOPITT), but there were some notable biases compared with Tropospheric Emission Spectrometer (TES) ozone. Compared with TES, our ozone predictions are high-biased in the upper troposphere, particularly in the south during January. This publication documents the global simulation database, the tool for conversion to LBC, and the
\end{abstract}

evaluation of concentrations on the boundaries. This documentation is intended to support applications that require representation of long-range transport of air pollutants.

\section{Introduction}

The role of hemispheric transport of air pollutants is increasingly a focus of regional pollution studies (Lin et al., 2000, 2012; Reidmiller et al., 2009). The growing emphasis reflects three factors: (1) the National Ambient Air Quality Standards have been tightened (40 CFR 50.10); (2) influence of international activities has increased average hemispherically transported pollutants (Cooper et al., 2010; Fiore et al., 2009; Oltmans et al., 2006, 2010) and (3) long-range transport can have episodic strong influence (Fiore et al., 2002). Thus, model attainment demonstrations must achieve lower pollutant concentration fields with a higher uncontrollable fraction. Under these conditions, it is imperative for the model to include long-range transported air pollution concentrations and accurately represent their variability in time and space. The long-range transported air pollutants are primarily communicated to air quality models (AQMs) through the lateral boundary conditions (LBC). This paper documents the development and availability of a resource that provides LBC for the air quality modeling community.

The surface level ozone concentrations have a $10-15 \mathrm{ppb}$ sensitivity to LBC values even in locations relatively far from the boundary (Napelenok et al., 2011). Much of the model 
sensitivity can be attributed to high mixing ratios $\left(\mathrm{O}_{3}=\right.$ 100-1000 ppb) in the upper troposphere/lower stratosphere (Krueger and Minzner, 1976; Lacis et al., 1990; Warneck and Williams, 2012). The high concentrations aloft are influenced by local emissions, international transport (Dentener et al., 2010; Lin et al., 2012), and stratosphere-troposphere exchanges (Bourqui et al., 2012; Cui et al., 2009; Lefohn et al., 2011). The LBC, particularly at high altitude, is a mechanism of communicating each of these sources to the continental domains often used in regional air quality simulations.

Previously, LBC have come from a variety of sources and have been evaluated indirectly. The Community Multiscale Air Quality (CMAQ; Foley et al., 2010) model originally used "clean air" estimates or observations averaged over space and time, but preserving the vertical dimension where possible (e.g., ozone based on Logan et al., 1999). These vertical profile lateral boundary conditions (PLBC) have obvious limitations. The observations used to construct PLBC are sparse in space and time and, therefore, interpolation and extrapolation are unavoidable. As a result, variability in space and time is lost. Although utilizing "clean air" estimates is still common (Gégo et al., 2008; Godowitch et al., 2008; Smyth et al., 2009; Zhang et al., 2004), increasingly publications recognized these limitations and the growing availability of global simulations to provide estimates of air pollution concentrations with time resolution ranging from hourly to seasonal mean (Appel and Gilliland, 2006; Barna and Knipping, 2006; Fu et al., 2009; Hogrefe et al., 2008; Jiménez et al., 2007; Lam and Fu, 2009; Nghiem and Oanh, 2008; Schichtel et al., 2005; Valari et al., 2011). By themselves, these global simulations are too coarse for regional/urban air quality standard attainment demonstrations, but they offer a potential source of LBC for regional/urban AQM (Appel and Gilliland, 2006; Lam and Fu, 2009; Song et al., 2008).

The importance of evaluating LBC is evident in sensitivity analysis (Barna and Knipping, 2006; Jiménez et al., 2007; Napelenok et al., 2008), but most LBC evaluations are indirect. When modeling the contiguous United States (CONUS), most of the LBC are over water. As mentioned above, these locations have a paucity of observational data. As a result, the accuracy of the LBC inputs is evaluated based on alternate locations. For example, Lam and Fu (2009) first evaluated model predictions based on three ozonesonde sites over the CONUS (Trinidad Head, CA; Boulder, CO; Huntsville, AL). They further indirectly evaluated the LBC fitness based on model performance at surface locations. Although air quality models have many degrees of freedom to isolate LBC, this type of indirect evaluation has been necessary. Even these indirect evaluations concluded that GEOSChem LBC (GLBC) outperformed clean air profiles and climatological averages (Appel and Gilliland, 2006; Lam and $\mathrm{Fu}, 2009$; Song et al., 2008). This conclusion gives some credence to the GLBC values, but in this report, we will further evaluate the GLBC using space-time coincident measurements available from satellite retrievals.

This document is structured according to the process of creating and evaluating LBC. The first section describes the details of the GEOS-Chem simulations used to create a database of global concentration fields for LBC. The second section documents the design, components, and functionality of the tool designed to create GLBC from GEOSChem outputs. The third section details the methods and results of evaluating GLBC using satellite observations. The conclusions review the usability of the tool and the fitness of database results. Finally, we discuss the availability of the LBC tool and global simulation database for the community.

\section{GLBC simulation database}

While LBC may be improved by global atmospheric modeling, the development and testing of global models is beyond the resources and scope of many air quality modeling studies. In order to provide users of regional AQM with global model information for boundary conditions in regional domains, a series of GEOS-Chem simulations have been conducted and are available for download with tools to produce regional model-ready boundary files.

GEOS-Chem is actively engaged in research projects with scientific groups across the world continuously improving the model code, chemistry formulation, and input information (details of the ongoing work on GEOS-Chem can be found at the model wiki page: http://wiki.seas.harvard.edu/ geos-chem/). Continual improvements to the model and a variety of chemistry, meteorology, and emission options within GEOS-Chem pose a challenge for regional air quality modelers in choosing the optimal model setup for generating LBC.

To address this, we have conducted a series of preliminary GEOS-Chem simulations at $2^{\circ} \times 2.5^{\circ}$ horizontal resolution spanning multiple model release versions and input options. Hourly concentrations for North America from all of these simulations are archived and available for download. Due to data storage considerations, only the hourly values for grid cells containing and surrounding the contiguous United States are archived (Fig. 1). Plans are underway to expand availability to global coverage. For each day, we archive composition files. Creation of LBC from GEOS-Chem requires two output files because some explicit species are not typically saved. To reduce computational burden, GEOS-Chem combines several chemical species into "tracer" groups at time of advection. These tracer groups are then converted back into chemical species ("cspec") during the chemical calculations. Since some chemical species are important when mapped to regional models (Pye and Napelenok, 2013), both the GEOS-Chem tracer and cspec arrays are included in the LBC archive. 


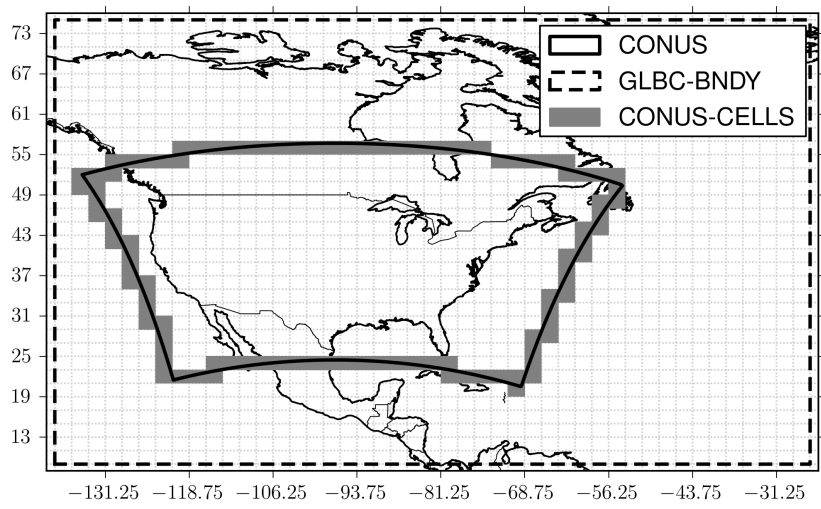

Fig. 1. GEOS-Chem lateral boundary condition output domain (GLBC; black dashed line) with the CONUS domain (black line) and grid cells that intersect the CONUS domain boundary.

Details of the model setup for each of the available simulations are listed in Table 1. Table 1 details combinations of GEOS-Chem model versions, chemistry version, meteorology data sets, shipping emissions, and time period covered. All simulations used GEOS-Chem's $\mathrm{NO}_{\mathrm{x}}-\mathrm{O}_{\mathrm{x}}$-hydrocarbonaerosol configuration with the optional Secondary Organic Carbon Aerosol module enabled. Versions of the chemical mechanism will be discussed further below. Whenever possible, the simulations follow GEOS-Chem manual recommended settings. The Sparse Matrix Vectorized Gearbased solver (Jacobson and Turco, 1994) is employed to solve the system of partial differential equations representing emissions and chemistry. Vertical mixing was solved using the non-local planetary boundary layer scheme and explicit cloud convection.

Emissions for these simulations closely follow the default configuration of GEOS-Chem. For emissions, the Emission Database for Global Atmospheric Research (EDGAR) provides global anthropogenic emissions (Berdowski et al., 2001) with regions overwritten where available. Regional anthropogenic emissions are provided by specific databases for the United States (NEI2005; US EPA, 2013), Europe (UNECE/EMEP; Vestreng and Klein, 2002), Mexico (BRAVO; Kuhns et al., 2003), Canada (CAC, Environment Canada, 2013), and Asia (INTEXB, Streets et al., 2003, 2006). In addition, the emissions include lightning $\mathrm{NO}_{\mathrm{x}}$ (Ott et al., 2010; Pickering et al., 1998; Price and Rind, 1992), soil $\mathrm{NO}_{\mathrm{x}}$ (Wang et al., 1998; Yienger and Levy, 1995), oceanic dimethyl sulfide, volcanic $\mathrm{SO}_{2}$, sea salt, wind-blown mineral dust, wildfires from the Global Fire Emissions Database (Werf et al., 2006) and biogenic volatile organic compound emissions from Model of Emissions of Gases and Aerosols from Nature (MEGAN) version 2.1 (Guenther et al., 2012).
Table 1. GEOS-Chem annual simulations for CMAQ boundaries (recommended in bold).

\begin{tabular}{lcccc}
\hline $\begin{array}{l}\text { GEOS-Chem } \\
\text { version }\end{array}$ & $\begin{array}{c}\text { Chemistry } \\
\text { version }\end{array}$ & Meteorology & $\begin{array}{c}\text { Shipping } \\
\text { emissions }^{\text {a,b }}\end{array}$ & $\begin{array}{c}\text { Simulation } \\
\text { years }^{\mathrm{c}}\end{array}$ \\
\hline v9-01-01 & v8-02-04 & GEOS-5 & EDGAR & $2004-2006$ \\
v9-01-02 & v8-02-04 & MERRA & EDGAR & $2001-2008$ \\
v8-03-02 & v8-02-04 & GEOS-5 & EDGAR & $2004-2007$ \\
v8-03-02 & v8-02-01 & GEOS-5 & ICOADS & $\mathbf{2 0 0 4 - 2 0 1 2}$ \\
v9-01-02 & v8-02-01 & MERRA & ICOADS & $\mathbf{2 0 0 1 - 2 0 1 0}$ \\
\hline
\end{tabular}

${ }^{a}$ ICOADS is the default (recommended) ship emission inventory (http://wiki.seas.harvard.edu/geos-chem/index.php/EDGAR_anthropogenic emissions\#Ship_emissions). ${ }^{\mathrm{b}}$ In GEOS-Chem simulations below v9-01-01, US biofuel emissions were erroneously excluded when using the NEI2005 inventory. In versions v9-01-01 and later, NEI1999 biofuel emissions are used. ${ }^{\mathrm{c}}$ Years shown are inclusive. First year is spinup.

Two versions of the chemistry were initially evaluated because of recent updates to GEOS-Chem's chemical mechanism. In an update in the chemistry mechanism between GEOS-Chem versions v8-02-01 and v8-02-04, the isoprene nitrate yield was decreased. Decreasing the yield of isoprene nitrate enhances radical cycling, increases simulated ozone concentrations. Because modeled ozone concentrations already have high positive biases in North America (Mao et al., 2013), this bug fix may lead to increased ozone biases in regional models by inflating the amount of ozone entering the regional domain from the boundaries. Improvements to halogen and heterogeneous aerosol chemistry have shown promise in reducing this high bias (Mao et al., 2013), but are not included, as these updates are still the subject of continuing research. Since the goal of including boundary conditions is to reduce overall bias within the regional simulation, we recommend using the chemistry mechanism from GEOS-Chem version v8-02-01 without updated isoprene nitrate when results are used for boundaries in applied regional simulations.

Performing simulations from 2001 to 2010 required the use of two meteorological data sets. The GEOS-5 data set (Molod et al., 2012) was used to drive GEOS-Chem simulations from 2004 to 2012, but was not available before. The MERRA data set (Rienecker et al., 2011) was available from 2001 to 2010. Using the MERRA data set, however, is only supported by GEOS-Chem version 9. Version 9 also includes other updates (full documentation available at http://acmg.seas.harvard.edu/geos/).

Several simulations using different combinations of model code and meteorological data sets were conducted (Table 1). Preliminary evaluations showed best performance from the GEOS-Chem version 8 simulations with GEOS-5 meteorology, version 8-02-01 chemistry, and ICOADS shipping emissions. Model version 9 with MERRA meteorology is also made available for the years 2001 through 2003. When 2001-2003 boundaries are necessary, an additional evaluation should be performed for that application. Based on preliminary analysis, only the results from MERRA (model v9) 
and GEOS-5 (model v8) with v8-02-1 chemistry have been archived. The evaluation section of this paper will focus on the GEOS-Chem version 8-03-02 model with version 8-0201 chemistry, and ICOADS shipping from 2006 to 2010.

\section{GLBC tool description}

Model compound translation (GEOS-Chem to regional model compounds) and spatial mapping of the global output to LBC are served by two distinct components in the GLBC tool. Model compound translation is performed by a Python (python.org) pre-processor, and a Fortran program handles spatial mapping. A flowchart of the overall program is shown in Fig. 2 and each component is described below.

\subsection{Python pre-processing}

The Python pre-processor interprets model configurations and user inputs to apply appropriate scaling. Both GEOSChem and CMAQ have several chemistry/aerosol configurations that continue to evolve. The pre-processor interprets configurations files and provides failsafe measures to prevent mapping of incorrect model versions and highlight potential errors. In addition, the pre-processor is able to apply unit conversions when appropriate.

To perform these tasks, the pre-processor must first interpret the model gas-phase and aerosol-phase configurations. From CMAQ, the pre-processor requires the namelists $(* . n m l)$ or include files $(*$.EXT) that describe the gas-phase $\left(\mathrm{GC}_{-}{ }^{*}\right)$, aerosol $\left(\mathrm{AE}_{-}{ }^{*}\right)$, non-reactive $\left(\mathrm{NR}_{-}{ }^{*}\right)$, and tracer (TR_*) species. From GEOS-Chem, the pre-processor requires the tracer_info.dat file. The final input is a user configuration file that will be described further below.

Mapping between GEOS-Chem and CMAQ species requires human interpretation. Each model has its own definition of gas-phase and aerosol-phase speciation. Even common elements are named inconsistently (e.g., formaldehyde $=\mathrm{FORM}=\mathrm{HCHO}=\mathrm{CH}_{2} \mathrm{O}$ ). The default compoundmapping file shown as a csv file with a bold outline in Fig. 2 is described in detail below to facilitate user creation of new mapping files. For the most common configurations of GEOS-Chem and CMAQ, species mapping is already provided for several chemical mechanisms (e.g., Carbon Bond '05, SAPRC07T - provided in supplemental Tables A1 and A2). For these mechanisms, the species mapping has already been done and no manual interpretation is necessary. Ideally, any new mapping configuration files will be submitted back to the software package for subsequent distribution to other users. The mapping file contains one or more lines for each output boundary species. The individual lines represent algebraic transformations excluding unit conversion, which is mostly automatic. The numbered lines below are example lines from the species-mapping file with the regional model (e.g., CMAQ) species listed first followed by the global model (GEOS-Chem) formula.
1. $\mathrm{O}_{3}, \mathrm{O}_{\mathrm{x}}-\mathrm{NO}_{\mathrm{x}}$

2. ALD2, ALD2

3. PAR, 4. *ALK4

4. ASO4K, $0.0776 *$ SALC

5. ASO4K, $0.02655 * \mathrm{DST} 4$

6. ASO4K, $0.02655 * \mathrm{DST} 3$

7. ASO4K, $0.02655 * \mathrm{DST} 2$

\section{8. $\mathrm{ASO} 4 \mathrm{~K}, \mathrm{SO} 4 \mathrm{~s}$}

Mapping assumes that the formula is based on GEOSChem tracers. If the name indicated is not found in the tracer file, the species (cspec) file will be searched. Line 1 is currently configured for the GEOS-Chem tracer file. The GEOSChem version 8 tracer file does not include ozone explicitly, but rather $\mathrm{O}_{\mathrm{x}}$ or odd oxygen. The "cspec" file includes ozone explicitly as " $\mathrm{O}_{3}$ ", so if line 1 is replaced with " $\mathrm{O}_{3}, \mathrm{O}_{3}$ " and the mapping tool would first try to find $\mathrm{O}_{3}$ in the tracer file, not find it, and then search and find " $\mathrm{O}_{3}$ " in the "cspec" file.

Caution is advised when using values contained in the "cspec" file. For example, in the stratosphere, the "cspec" file does not contain meaningful values. These values are generally not updated or accessed by the GEOS-Chem simulation, and should not be used for LBC if information is available in the tracer file.

Line 2 and 3 illustrate the difference between the quantities stored in CMAQ LBC files and GEOS-Chem tracer files. ALD2, or acetaldehyde, is stored as parts per billion of carbon (ppbC) in GEOS-Chem and ppb in CMAQ. Since acetaldehyde has two carbons, the GEOS-Chem value is automatically converted to ppb. The ALK4 species is also stored as ppbC and automatically converted to ppb. In Carbon Bond, alkanes are stored as 4 paraffin carbon bonds.

Aerosol species in GEOS-Chem, such as wind-blown mineral dust and sea salt, are speciated into individual aerosol constituents (Appel et al., 2013), and lines 4-7 demonstrate how GEOS-Chem aerosols such as SALC and DST2 are mapped based on CMAQ emission profiles for assignment to coarse mode sulfate.

Lines 4-8 above demonstrate that additional lines are additive. Because the lines are additive, these lines could have been re-written as a single line, "ASO4K, $\quad 0.0776 *$ SALC + 0.02655 * (DST2 + DST3 + DST4) + SO4s".

The mapping expressions can include all standard Python operators $(+,-, *, /, * *, \%$, etc.). Thus, any combination of GEOS-Chem simulated species may be mapped to modeled species using basic algebra. With more complex mathematical representations, a user could develop algorithms for mapping tracers to models with, for example, modal size distributions. In addition, empirical regression relationships 


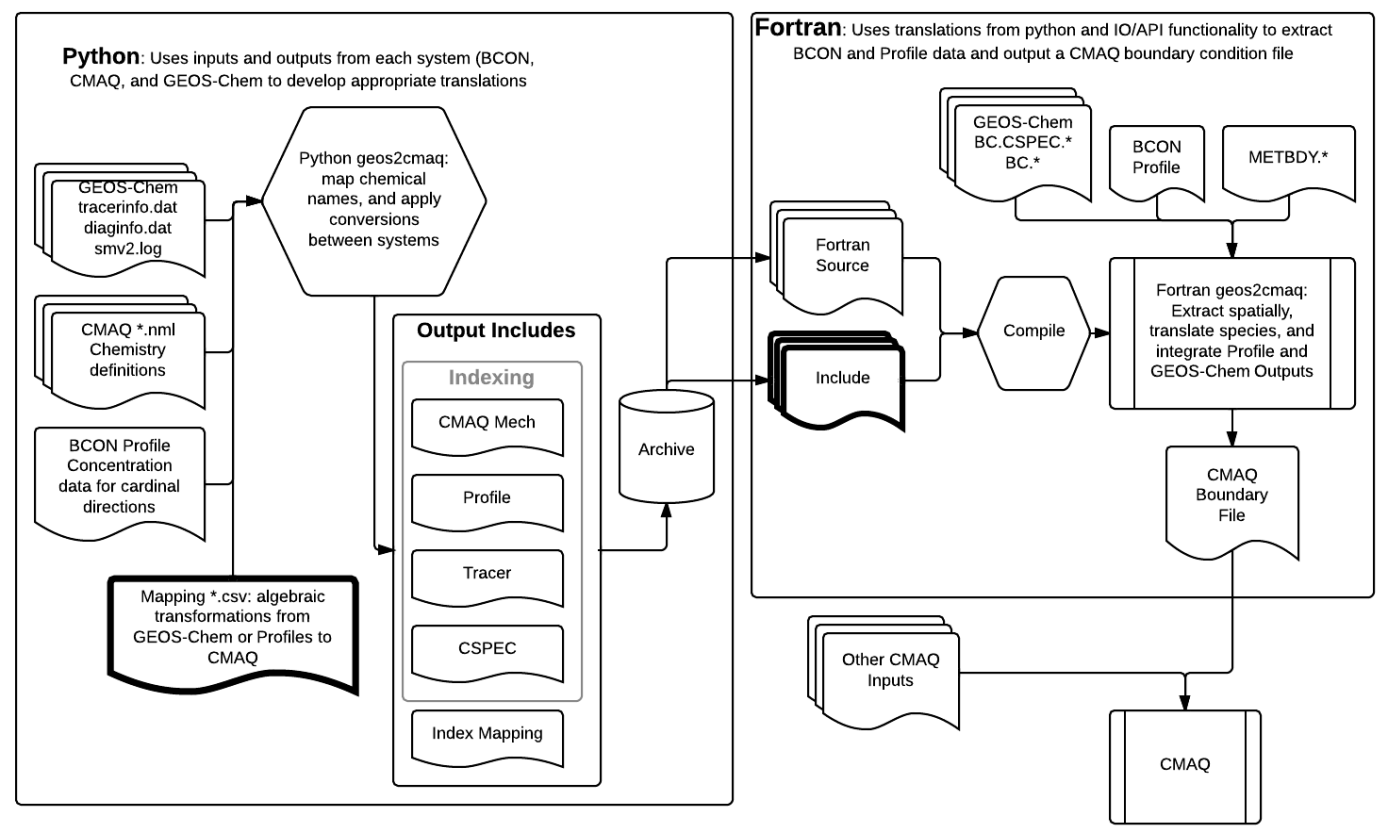

Fig. 2. Program description and flow UML diagram. The BCON and BC.CSPEC.* files are not required. Heavy lined inputs represent geos2cmaq-specific inputs or outputs (i.e., not also necessary for standard run).

could be used to develop boundary concentrations for species that are not simulated by GEOS-Chem. In a beta version of the code, arbitrary math functions (e.g., sin) are available, but require advanced knowledge of Python and NumPy (http://www.numpy.org/). The flexible syntax allows for creative applications to other studies.

There are five types of factors that are routinely applied:

1. Speciation of lumped GEOS-Chem things (like sea salt, dust, PRPE, etc.) to individual CMAQ species when the CMAQ representation is more detailed/speciated.

2. Conversion of real species to CB05/SAPRC mechanism species (like multiplying ACETONE by 3 for PAR).

3. Conversion of tracers in $\mathrm{ppbC}$ to $\mathrm{ppb}$ (like dividing benzene by 6 ).

4. Conversion of tracers to functional groups (e.g., $\mathrm{ALK} 4=4 * \mathrm{PAR})$.

5. Conversion to regional model units.

Type 1 and 2 require algebraic expressions in the mapping file. Type 3 does not require expressions because the Python pre-processor will automatically convert ppbC to ppb. Type 4 is a special case of type 3 where the regional model's conversion to ppb must be overridden in the file. Type 5 is treated automatically, converting ppb to $\mu \mathrm{g} \mathrm{m}^{3}$ for aerosols and $\mathrm{ppb}$ to ppm for gas-phase species.

\subsection{Fortran spatial mapping}

The Fortran-based spatial mapping program uses 3 required inputs and 2 optional inputs. The software first requires the output from the species-mapping Python pre-processor described above. The species mapping is simply applied in concert with the spatial mapping.

The software also requires a GEOS-Chem tracer output file and, optionally, a chemical species ("cspec") output file. The GEOS-Chem files have sufficient meta-data to identify the files' spatial location and extent based on the well-documented GEOS-Chem domains (Yantosca et al., 2012). The vertical coordinate is specified in the GEOS_DOMAIN.INC file, which re-writes the GEOSChem hybrid-eta coordinates as a sigma-P coordinate.

Finally, the software requires a meteorological input file, METBDY3D produced by a CMAQ utility (Otte and Pleim, 2010), which contains sufficient information to describe the centroid locations of each boundary cell, the vertical location on a sigma-P coordinate, and air density. The Fortran program selects a GEOS-Chem column/row using the "nearest neighbor" algorithm based on the regional model and GEOSChem centroids. Figure 1 shows the intersection of an example boundary and the GEOS-Chem outputs. The GEOSChem concentrations are then interpolated from the GEOSChem hybrid-eta levels to the regional model coordinate. This is done by first calculating each layer-center pressure for GEOS-Chem and the regional model, and then linearly interpolating. The archive only has GEOS-Chem results up to either the 34 th layer $(100 \mathrm{hPa})$ or the 38 th layer $(40 \mathrm{hPa})$. 
In the case where the regional model coordinate is outside the range of GEOS-Chem, the concentrations are extrapolated by default. This extrapolation can be disabled in the code.

High ozone in the upper troposphere is known to have undue influence on models with coarse vertical resolution. Simulations using coarse vertical resolution may need to reduce the influence of aloft ozone LBC. For example, previous work has shown that coarse vertical resolution can cause bias due to high ozone near the tropopause (Lam and Fu, 2009). We include tools for excluding stratospheric air from LBC, but do not recommend its use unless specifically desired.

Exclusion of stratospheric air has been suggested on the basis that AQM do not explicitly treat the stratosphere (Lam and $\mathrm{Fu}, 2009$ ). Since that publication, there has been more work identifying the importance of stratospheric air in air quality (e.g., Lefohn et al., 2011). Air quality models have increased their vertical extent and now often include stratospheric influence, if not stratospheric air (e.g., Carlton et al., 2010). To account for the stratosphere, efforts have been made to scale the upper layer concentrations based on stratospheric indicators (Lin et al., 2008). As such, LBCs that specifically exclude stratospheric air are not consistent with the need to include stratospheric influence in air quality models. Furthermore, reports show that vertically coarse models, like that used in Lam and Fu (2009), transported too much aloft air to the surface. This suggests that, while stratospheric air is an important contributor to variability, previous models would have optimal solutions that minimized aloft LBC values. The use of indirect evaluation, like interior domain surface concentrations, is inherently subject to canceling errors (e.g., Oreskes et al., 1994).

\section{GLBC evaluation}

This section describes the evaluation of GLBC using satellite retrievals. While ozonesondes are often considered the gold standard for evaluating satellite products (Nassar et al., 2008; Worden et al., 2007), they are not available at the boundary locations. In this analysis, we evaluate the LBC ozone values using two satellite products for ozone and one for carbon monoxide. Aerosol species are provided in the database to provide consistent boundary conditions, but have not been evaluated here. To evaluate the model, we pair satellite retrievals with GEOS-Chem grid cells from five years, 2006 to 2010, for two months. January results are selected to represent winter and August results are selected to represent the traditional ozone season. Details of the satellite products and model processing for comparison with retrievals are discussed below, followed by satellite and model processing details.

Ozone retrievals are taken from the Tropospheric Emission Spectrometer (TES) and the Ozone Monitoring Instrument (OMI). The TES instrument uses infrared Fourier transform spectroscopy to retrieve ozone vertical profiles (Bowman et al., 2011) from the Aura satellite and is limited to nadir scanning in this paper. We are using version 4 (V004) that has improved performance compared with V001 evaluated by Worden et al. (2007), but which has a 5-15\% high bias consistent with Nassar et al. (2008). Although the evaluation below will be performed in an absolute sense, the interpretation of these results must account for TES's unresolved high bias. Although the evaluation is nominally for 2006 to 2010 , TES profiles were not available for January of 2010. Data for all other months was downloaded from http://avdc.gsfc.nasa. gov/download_2.php?site=634280718\&id=60.

The OMI instrument measures ozone from the Aura satellite. We use the Level 2 OMI ozone profile (OMO3PR) version 3. Files were downloaded from NASA's Mirador website, and filtered using the recommended bitwise and calculation of the ProcessingQualityFlags (i.e., ProcessingQualityFlags \& 43679). The OMI ozone data was available for all the years and months.

The MOPITT instrument is aboard the Terra satellite and measures carbon monoxide. MOPITT retrieves carbon monoxide by differential absorption of light in infrared absorption bands. The carbon monoxide measurement is translated into a vertical profile using a retrieval algorithm described by Deeter et al. (2003). We are using the MOPITT carbon monoxide Level 2 product version 6, which uses only thermal infrared radiances (MOP02T). Data files were downloaded from NASA's Reverb website http://reverb.echo.nasa. gov/reverb, with no additional filtering. The MOPITT carbon monoxide data were not available for August of 2009, so that month will not be evaluated.

The GEOS-Chem grid cells are filtered for just those that would be used in creating CONUS boundary conditions (see Fig. 1). GEOS-Chem grid cells are then paired with satellite pixel centroids when the pixel is contained within the grid cell. After pairs have been identified, the satellite retrieval algorithms are applied to GEOS-Chem using Eq. (1) for TES and OMI. Equation (1) follows the Bowman et al. (2011, Eqs. 5-8) methodology and has the effect of smoothing model results vertically. Smoothing is required because the satellite estimates at each pressure level are sensitive to concentrations at other pressure levels.

$\widehat{\boldsymbol{y}}_{t}^{i, m}=\boldsymbol{y}_{t, c}^{i}+\mathbf{A}_{t}^{i}\left(\boldsymbol{y}_{t}^{i, m}-\boldsymbol{y}_{t, c}^{i}\right)+\varepsilon_{t}^{i}$,

where all $\boldsymbol{y}$ values are the natural $\log$ of the mixing ratio for ozone or carbon monoxide, $\boldsymbol{y}_{t}^{i, m}$ is the original model prediction, $\boldsymbol{y}_{t, c}^{i}$ is the a prior estimate, $\mathbf{A}_{t}^{i}$ is the averaging kernel, and $\varepsilon_{t}^{i}$ is an unknown error component. $\widehat{\boldsymbol{y}}_{t}^{i, m}$ is the model retrieval that can be directly compared with the satellite retrieval. In the evaluation shown here, the results have all been converted to mixing ratios (ppbV). Although the absolute value of $\widehat{\boldsymbol{y}}_{t}^{i, m}$ depends on the a prior $\left(\boldsymbol{y}_{t, c}^{i}\right)$, a comparison between $\widehat{\boldsymbol{y}}_{t}^{i, m}$ and the retrieval $\left(\widehat{\boldsymbol{y}}_{t}^{i}\right)$ does not (Bowman et al., 2011). This independence is mathematically shown in the TES User Guide. 

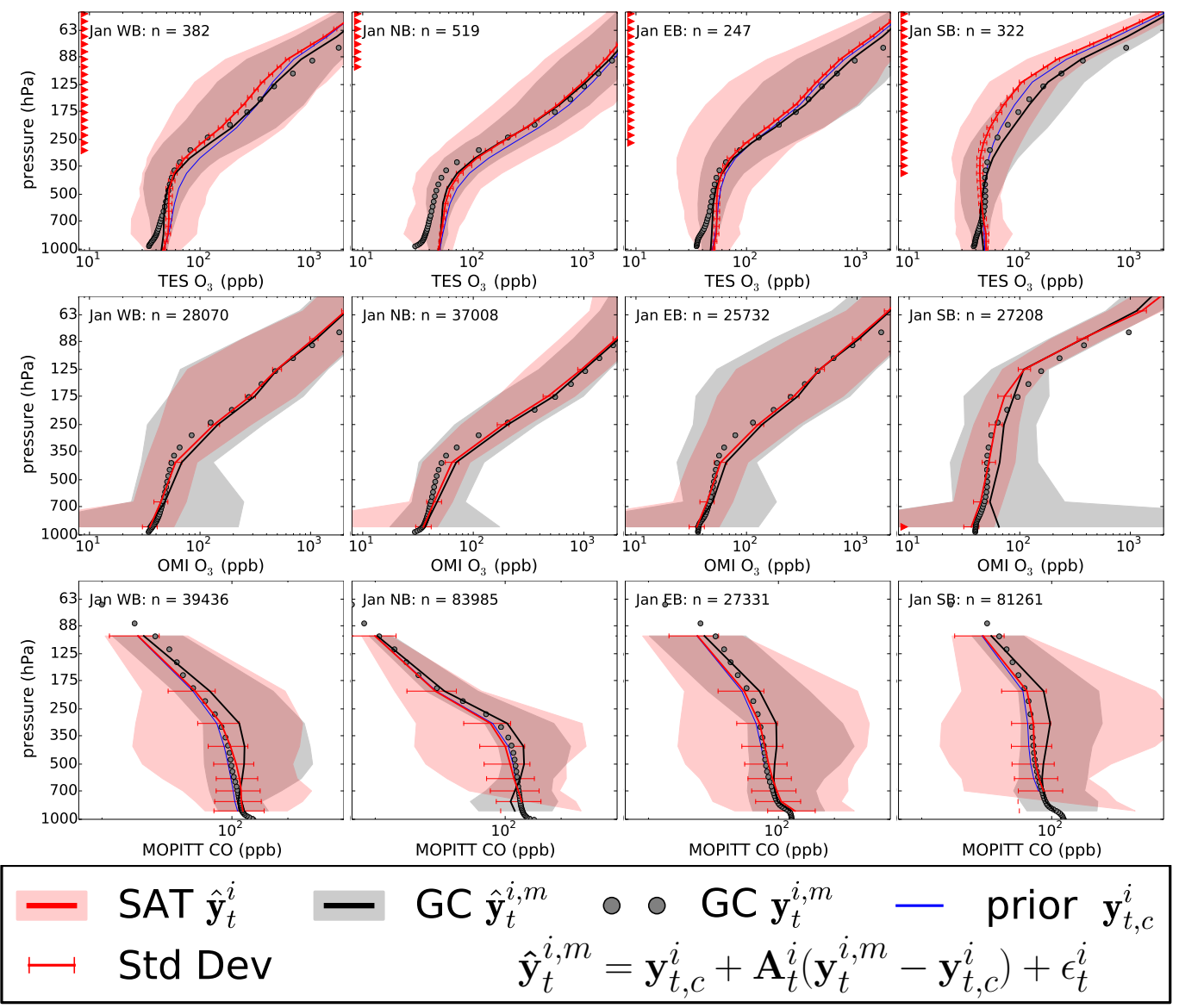

Fig. 3. Ozone and carbon monoxide mixing ratios (ppb) for January as observed by TES $\left(\mathrm{O}_{3}\right.$, row 1$)$, OMI $\left(\mathrm{O}_{3}\right.$, row 2$)$, and MOPITT $(\mathrm{CO}$, row 3) (SAT $\widehat{y}_{t}^{i}$, red) and retrievals from GEOS-Chem (GC $\widehat{y}_{t}^{i, m}$, black). GEOS-Chem retrievals are calculated by applying the satellite averaging kernel to the GEOS-Chem prediction (GC $\widehat{y}_{t}^{i, m}$, grey dots), which relies on the a prior (a prior $\widehat{y}_{t, c}^{i}$, blue). Lines or dots represent median values, the shaded area represents the range of values, and satellite uncertainty is shown as error bars. Red and blue triangles show high (red) and low (blue) biases as defined by 2 times the satellite error for the median value.

The evaluation has been performed by grouping grid cells by boundary face (West, North, East, South) on the CONUS domain. Based on pixel centroid locations during the $5 \mathrm{yr}$, there is a total of 274316 pairs with MOPITT carbon monoxide (January: 165 246, August: 109 070), 128186 pairs with OMI ozone (January: 64216, August: 63970), and 1753 pairs with TES ozone (January: 841, August: 912). The larger number of pixel pairs for MOPITT and OMI is expected because there are more pixels in their arrays.

For each satellite, biases were initially reviewed for 40 categories ( $5 \mathrm{yr} \times 2$ months $\times 4$ perimeter cardinal edges). The difference between years was nominal and is not highlighted here, but is included in the Appendix (Figs. A1-A6). Instead this paper will focus on results aggregated by month and boundary face (West, North, East, South). As previously noted, the GEOS-Chem database only has 34 or 38 layers. To minimize the influence of extrapolation on this analysis, above layer 34 extrapolated results are replaced with satellite estimates. Because extrapolation is optional, this seemed most appropriate.

Figures 3 and 4 show ozone and carbon monoxide (ppb) for each boundary face for January (Fig. 3) and August (Fig. 4). Each panel shows raw GEOS-Chem results, GEOSChem retrievals (Eq. 1), and satellite retrievals. To aid in interpretation, GEOS-Chem biases have been highlighted using triangles on the $y$ axis (red = high; blue = low) when the bias is greater than the twice observation uncertainty. To prevent spurious differences, we require that a student's $t$ test reject the null hypothesis that the distribution of model retrievals is the same as the satellite $(p<0.001)$. The mean and range of profiles show good correspondence most of the time. The MOPITT carbon monoxide and OMI ozone are in good agreement with GEOS-Chem. For TES, however, the evaluation shows some discrepancies. 


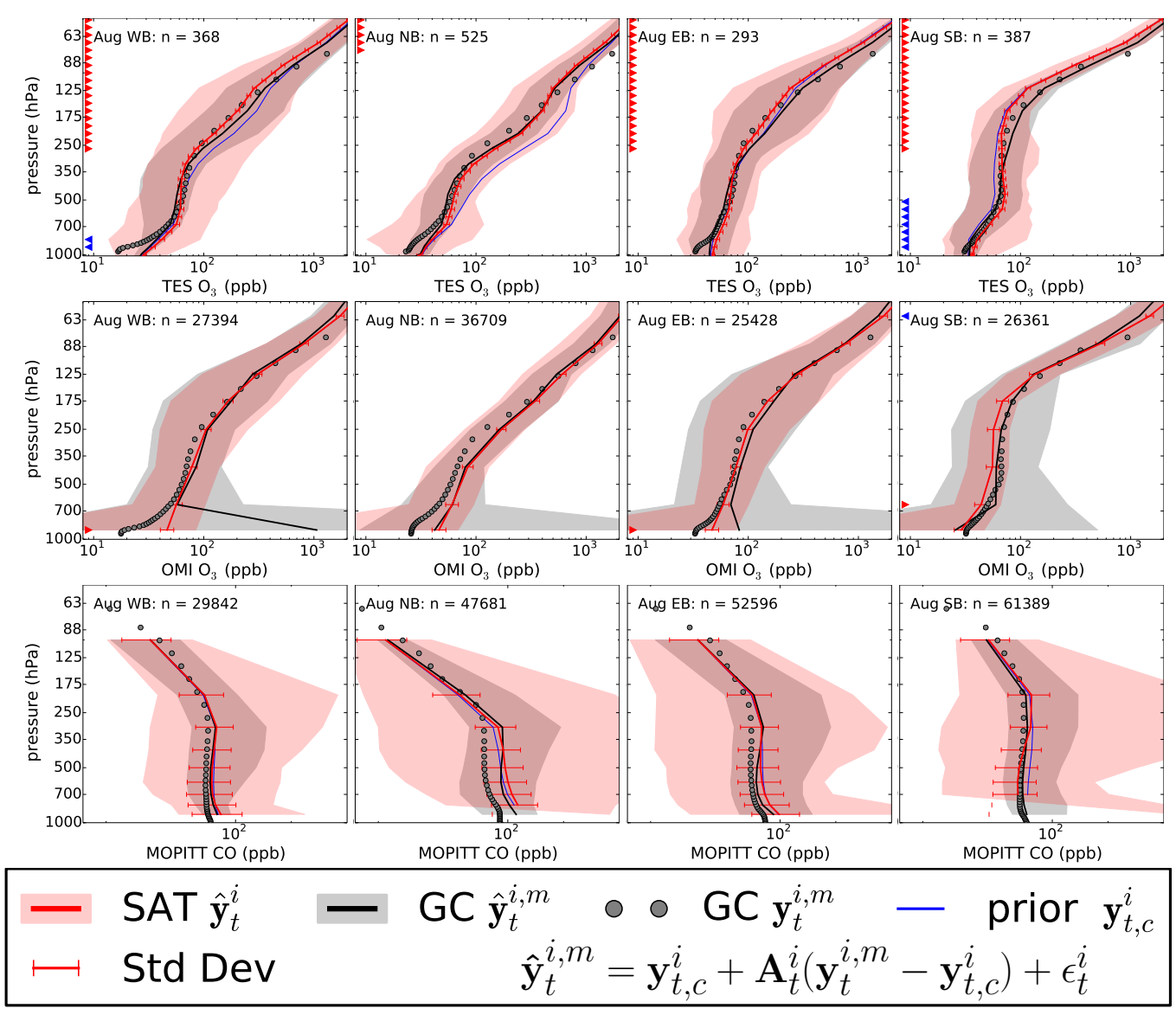

Fig. 4. Same as Fig. 3 for August.

The TES bias also exhibits time and space dependence. Figures 3 and 4 show distinct performance regimes above and below $350 \mathrm{hPa}$. Below $350 \mathrm{hPa}$, there is a transient low bias that is most pronounced in August. Above $350 \mathrm{hPa}$, there is a more persistent high bias. The high bias above $350 \mathrm{hPa}$ is higher in the West, South, and East faces compared with the North. The analysis thus far is based on the vertical profile of means and basic distribution statistics.

To further explore these aggregate biases, Figs. 5 and 6 show the distribution of individual retrieval biases for January (Fig. 5) and August (Fig. 6). The biases in Figs. 5 and 6 are shown as the ratio of retrieved mixing ratios (i.e., ppb). To reiterate, this type of comparison is not dependent upon the a prior - only the sensitivity of the instrument. Table 2 shows the percentage of pixels for each boundary face and for each month where the model and observed value are within $\pm 10 \%$ and $\pm 20 \%$. For most categories, $70-81 \%$ of MOPITT and OMI results are within $\pm 20 \%$ and $45-56 \%$ are within $\pm 10 \%$ of satellite retrievals. Only the OMI south faces has less than $70 \%$ (January $61 \%$ and August $66 \%$ ) within $\pm 20 \%$, and less than $45 \%$ within $\pm 10 \%$. TES shows more variable performance. Except for the North face, $56 \%$ or less of TES comparisons are within $\pm 20 \%$, and $32 \%$ or less are within $\pm 10 \%$.

The TES high bias above $350 \mathrm{hPa}$ is more pronounced in January than in August, and this significant bias correlates with an enhanced bias in the MOPITT carbon monoxide. For MOPITT, the biases are not outside of precision, but the correlation is intriguing. The biases in Figs. 3 and 4 and Table 2 correlate with latitude, with a stronger relationship aloft. For TES retrievals, the ratio model to satellite retrieval was regressed against latitude and longitude. The regression was performed for each layer for all January and August months. The January slope is strongest, as shown in Fig. 6, and ranges from $-1.05 \%$ at $316 \mathrm{hPa}$ to $-2.08 \%$ at $162 \mathrm{hPa}$. Although this explains only $15 \%$ of bias variability, the slope is statistically significant for latitude. For longitude, the slope is negligible and never significant.

\section{Conclusions}

We describe and evaluate a tool for using global simulations to produce LBC for regional air quality models. In general, the LBC performed well in evaluation for ozone and carbon 

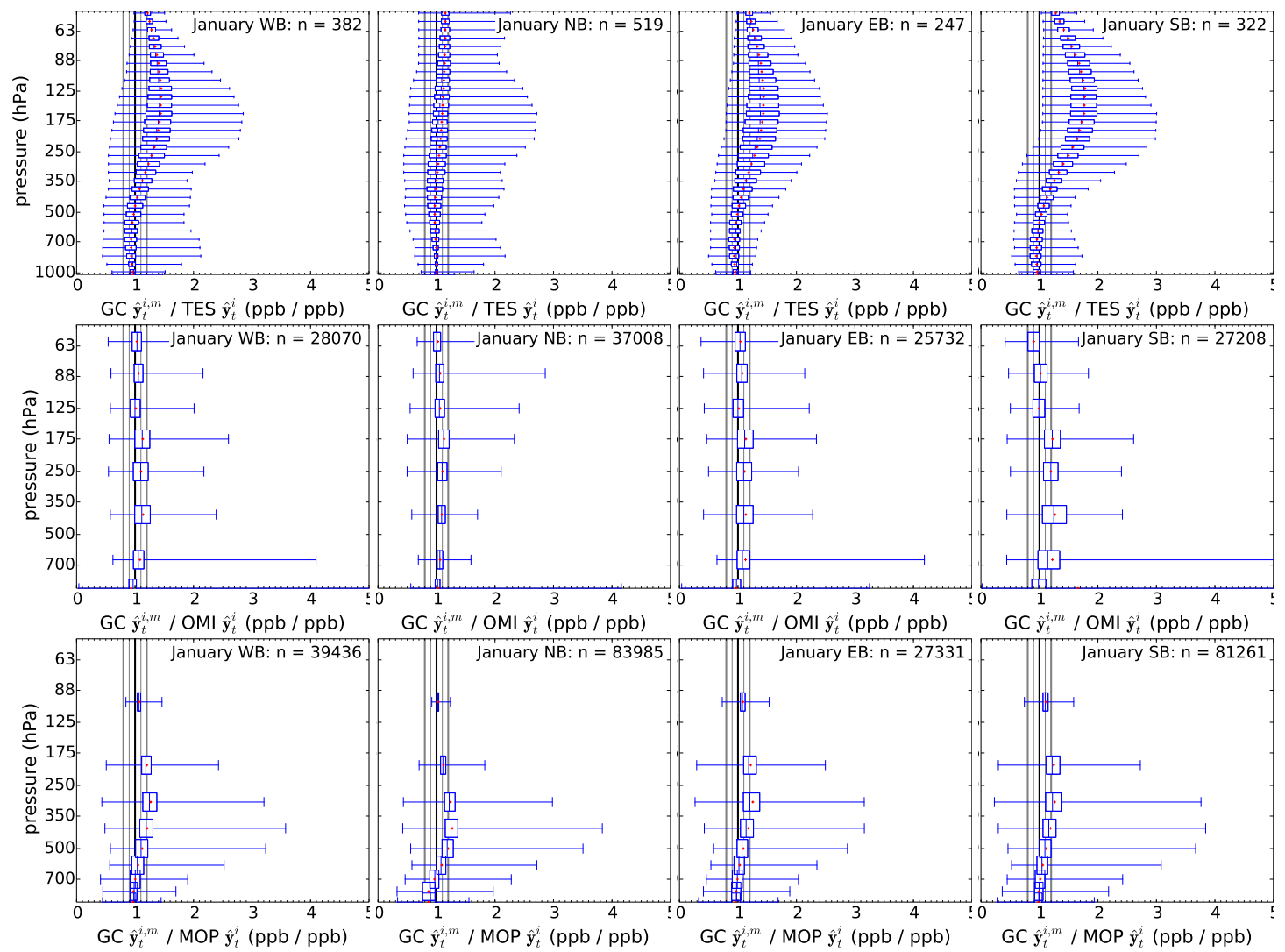

Fig. 5. Individual retrieval relative bias shown as boxplots for each altitude bin in each satellite product (TES, OMI, and MOP=MOPITT). Whiskers indicate $\min / \max$, the box represents the interquartile range, the blue line in the box is the median and the red cross is the mean. Vertical grey lines delineate the $\pm 10 \%$ (fine) and $\pm 20 \%$ (heavy) bias ranges.

Table 2. Percentage of retrieval values below $50 \mathrm{hPa}$ that are within 10 and 20 percent of TES, OMI, and MOPITT for each boundary face (West, North, East, and South) from 2006 to 2010.

\begin{tabular}{lcccccc}
\hline & \multicolumn{2}{c}{ TES } & \multicolumn{2}{c}{ OMI } & \multicolumn{2}{c}{ MOPITT } \\
Boundary & $\pm 10 \%$ & $\pm 20 \%$ & $\pm 10 \%$ & $\pm 20 \%$ & $\pm 10 \%$ & $\pm 20 \%$ \\
\hline January & & & & & & \\
\hline West & $27 \%$ & $48 \%$ & $50 \%$ & $77 \%$ & $49 \%$ & $75 \%$ \\
North & $49 \%$ & $77 \%$ & $59 \%$ & $86 \%$ & $45 \%$ & $70 \%$ \\
East & $31 \%$ & $52 \%$ & $48 \%$ & $75 \%$ & $48 \%$ & $76 \%$ \\
South & $19 \%$ & $34 \%$ & $34 \%$ & $61 \%$ & $45 \%$ & $73 \%$ \\
\hline August & & & & & & \\
\hline West & $32 \%$ & $56 \%$ & $49 \%$ & $81 \%$ & $56 \%$ & $81 \%$ \\
North & $47 \%$ & $77 \%$ & $57 \%$ & $90 \%$ & $51 \%$ & $75 \%$ \\
East & $30 \%$ & $56 \%$ & $46 \%$ & $76 \%$ & $48 \%$ & $75 \%$ \\
South & $27 \%$ & $50 \%$ & $36 \%$ & $66 \%$ & $48 \%$ & $75 \%$ \\
\hline
\end{tabular}

monoxide. There was a bias seen when comparing with TES retrievals. A persistent high bias was found in the upper troposphere (above $350 \mathrm{hPa}$ ). This bias is counterbalanced by good performance compared to OMI ozone evaluation and may be a limitation of our data set.
The model bias compared with TES may be the result of limited outputs at high altitudes. Our archived GEOS-Chem only includes levels below approximately $100 \mathrm{hPa}$. In comparing with TES, the averaging kernel effectively includes data from above $100 \mathrm{hPa}$ at several layers below $100 \mathrm{hPa}$. As 

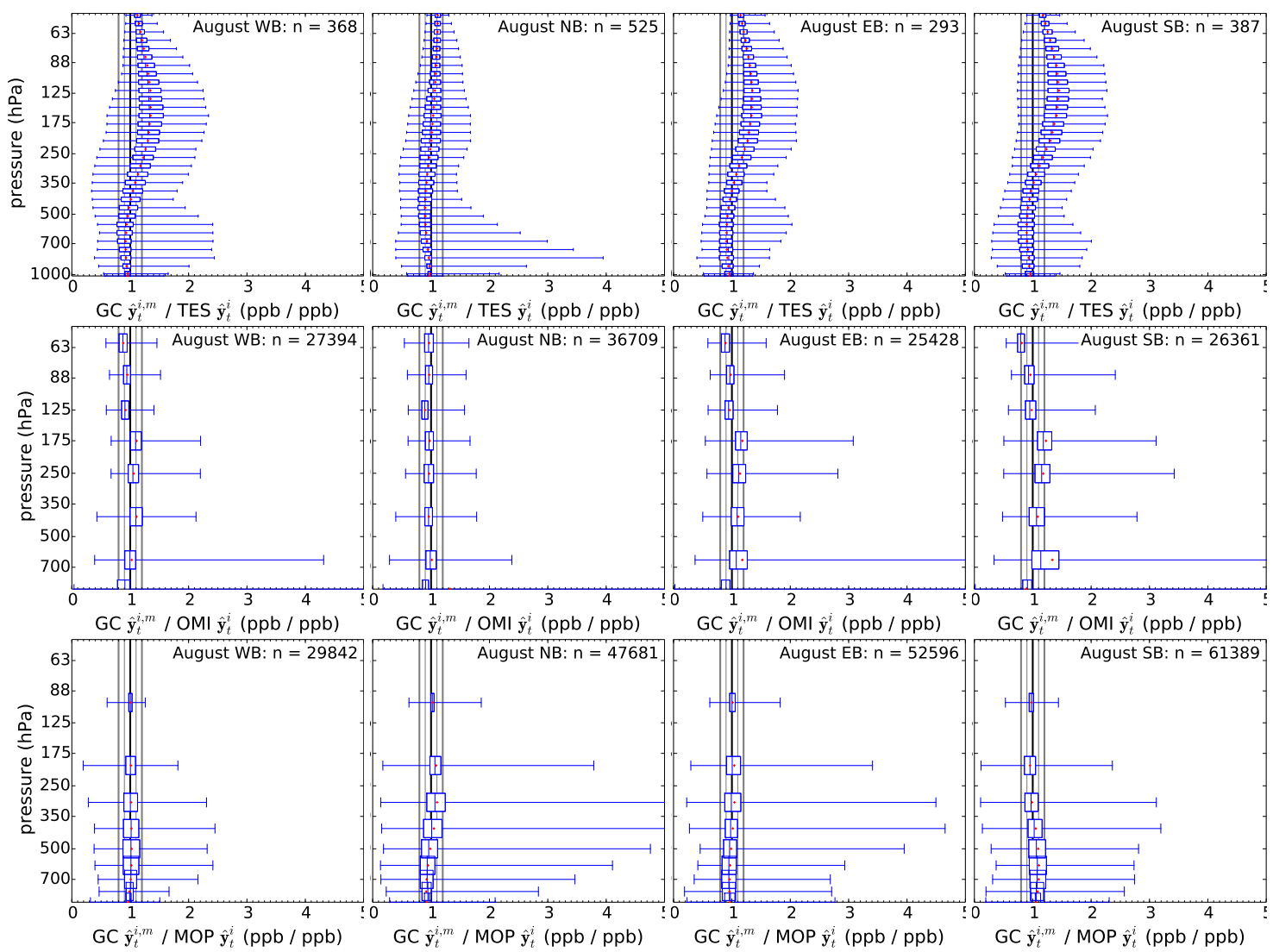

Fig. 6. Same as Fig. 5 for August.
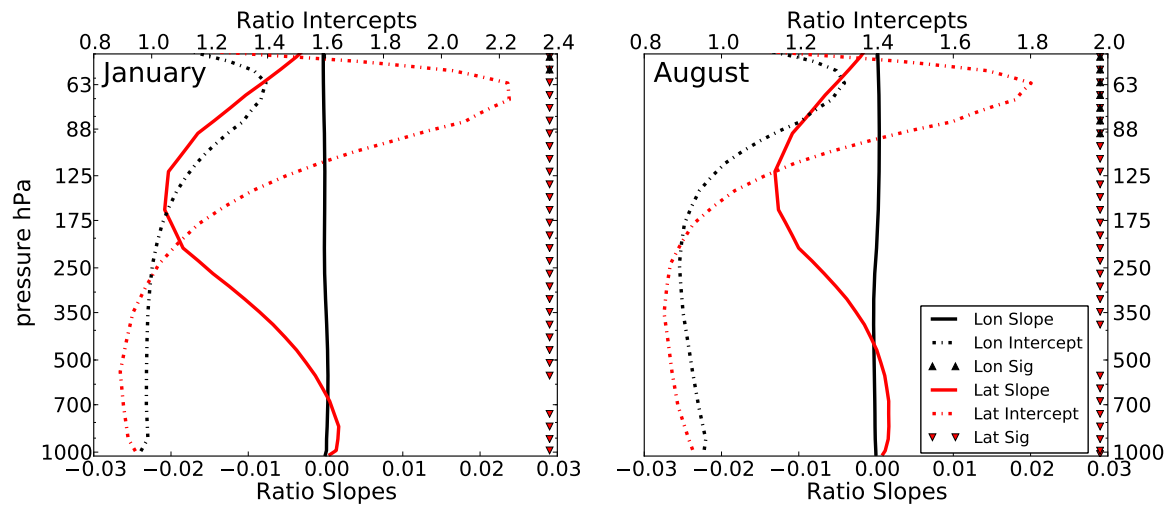

Fig. 7. Linear regression of slope (solid) and intercept (dash-dot) for the ratio of simulated retrieval to TES satellite retrieval as a function of longitude (black) and latitude (red) for January (left) and August (right).

such, the model bias compared with TES may be the result of an assumption made about our archived model data.

The altitude and timing of the bias compared with TES suggests an overestimation of long-distance transport. Our evaluation showed that the model performed better in August than in January. In January and at high altitudes, temperatures are low and ozone lifetimes are long. These conditions are ideal for highlighting ozone from continental outflow. More research is needed to understand the source of this bias, which could be transport or emissions. The emissions are implicated by the correlation between biases of carbon monoxide and ozone. This suggests upwind emissions, possibly from Asia, are overestimated. Asian emissions have grown rapidly and future projections shown continued 
growth (Ohara et al., 2007). This leads to high uncertainty in simulated Asian emissions that could contribute to the observed bias.

The presented tool provides a resource to better represent global transport through boundary conditions in regional air quality studies. Evaluations showed good mean performance, but the maximum bias was over a factor of five. This bias could either be the result of satellite uncertainties or model uncertainties. The role of uncertainty in boundary conditions can have strong impacts on regional model results. This will be particularly true for longer-lived compounds with direct impacts, like ozone. When specific episodes are critical to the model application, further application-specific evaluation will be necessary. The database's overall evaluation demonstrates the fitness for producing LBC.

Both the tool and the database are freely available. The database can be downloaded from the University of Florida's FTP server at ftp://data.as.essie.ufl.edu/pub/geos $2 \mathrm{cmaq}$ and the tool can be downloaded from http://github.com/barronh/ geos $2 \mathrm{cmaq}$. At the tool website, an example data set can be found with step-by-step instructions. The availability and usability of this tool serves the community need for lateral boundary conditions for regional modeling.

\section{Appendix A}

The Appendix contains species mapping for common gasphase and aerosol mechanisms and more detailed evaluation of ozone and carbon monoxide lateral boundary conditions. Tables A1 and A2 provide mapping details for Carbon Bond '05 and SAPRC07. These tables are followed by a detailed discussion of aerosol mapping for CMAQ's aerosol mechanism. Finally, the body of the paper discusses the aggregated years 2006 to 2010. The Appendix provides information on individual years.

\section{A1 Individual year evaluation}

See Figs. A1-A6.

\section{A2 Species mapping for gas phase}

See Tables A1 and A2.

\section{A3 Species mapping for CMAQ aerosols}

The CMAQ AERO6 aerosol module generally contains more detailed information regarding aerosol speciation and size than standard GEOS-Chem output. As a result, factors are applied to GEOS-Chem aerosols to convert them appropriately to CMAQ-ready boundary conditions. The conversions we recommend are shown in Table A3 and discussed below.
Both sea salt and dust in GEOS-Chem contain size information. Accumulation (SALA) and coarse (SALC) mode sea salts from GEOS-Chem are matched with the accumulation $(J)$ and coarse $(K)$ mode in CMAQ. Based on the particle size of the four GEOS-Chem dust size bins, the smallest dust (DST1) is mapped to the accumulation mode while all other bins (DST2-4) are mapped to the coarse mode. Speciation of sea salt into trace metals and other aerosol constituents is based on the same speciation profile that CMAQ uses for sea salt emissions diagnosed within the model. The speciation of wind-blown mineral dust also follows a speciation profile in CMAQ and is based on a composite of four desert dust profiles (Appel et al., 2013).

Sulfate, nitrate, and ammonium aerosols in GEOS-Chem (Park et al., 2004; Pye et al., 2009) do not explicitly contain size information, but are generally assumed to be representative of the accumulation mode. As a result, $99 \%$ of sulfate, nitrate, and ammonium are assigned to the accumulation $(J)$ mode while $1 \%$ is attributed to the Aitken (I) mode. Sulfate formed on sea salt $\left(\mathrm{SO}_{4} \mathrm{~s}\right)$ and nitrate formed on sea salt $\left(\mathrm{NO}_{3} \mathrm{~s}\right)$ (Alexander, 2005) are mapped to the CMAQ coarse mode. $99.9 \%$ of primary carbonaceous aerosols from GEOS-Chem are attributed to the accumulation mode while $0.1 \%$ are assigned to the Aitken mode, consistent with CMAQ emissions processing (Binkowski and Roselle, 2003, paragraph 12). Both hydrophobic (BCPO) and hydrophilic (BCPI) forms of black carbon in GEOS-Chem are summed together and mapped to elemental carbon (EC). Similarly, hydrophobic and hydrophilic organic carbon is mapped to primary organic carbon. The non-carbon organic matter (NCOM) associated with primary organic aerosols is not calculated by GEOS-Chem, so an OM/OC ratio of 1.4 is assumed for boundary condition purposes (Park, 2003).

Although CMAQ and GEOS-Chem both treat secondary organic aerosol from the same set of parent hydrocarbons, the species lumping schemes differ. In CMAQ, lumping is based on precursor hydrocarbon identity as well as volatility, while the GEOS-Chem SOA lumping scheme (Chung, 2002; Henze et al., 2008; Liao et al., 2007) generally does not separate based on volatility. The mapping of SOA as well as gas-phase semivolatiles is based on identifying the equivalent parent hydrocarbon in each model. Speciation to the different volatility species within CMAQ is based on the expected relative amounts of each species in outflow of the Eastern US as predicted by a typical CMAQ simulation.

The particle number and surface area for the boundary conditions are calculated in the Fortran code based on the mass mapped into each mode.

The following CMAQ aerosol species boundary conditions are not mapped since there is no analogous GEOS-Chem model species: AOLGBJ, AOLGAJ, AALKJ, SV_ALK, ACORS. Aerosol water is also not mapped as it is readily computed within CMAQ and does not need to be transported. 


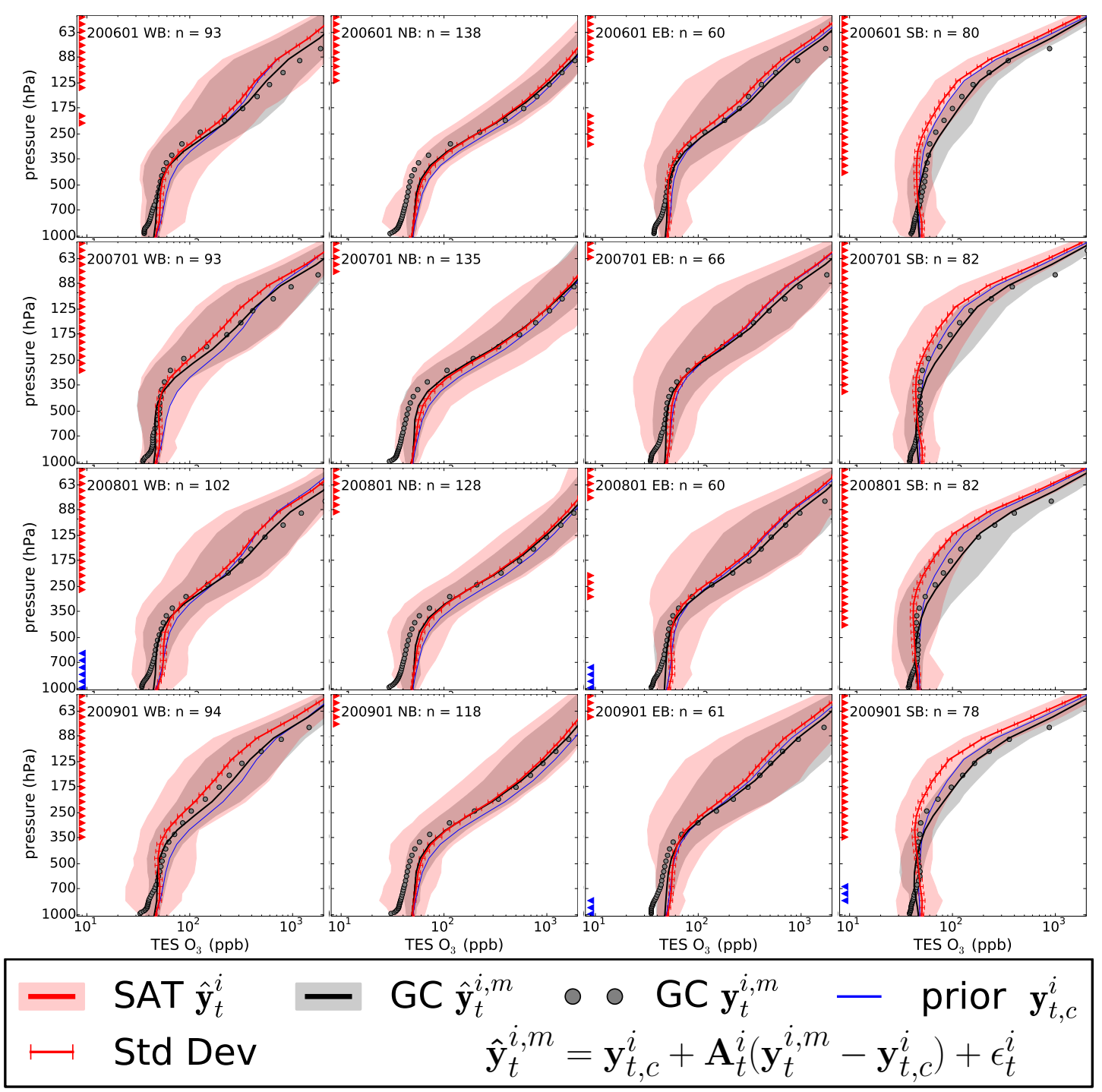

Fig. A1. Ozone retrievals from TES for January of 2006, 2007, 2008, and 2009 for each boundary face (West, North, East, South) observed by TES (TES $\widehat{y}_{t}^{i}$, red) and as retrieved from GEOS-Chem (GC $\widehat{y}_{t}^{i, m}$, black). GEOS-Chem retrievals are calculated by applying the TES averaging kernel to the GEOS-Chem prediction (GC $\widehat{y}_{t}^{i, m}$, grey dots), which relies on the a prior (a prior $\widehat{y}_{t, c}^{i}$, blue). Lines or dots represent median values, the shaded area represents the range of values, and TES uncertainty is shown as error bars. Red and blue triangles show high (red) and low (blue) biases as defined by 2 times the TES error for the median value. 


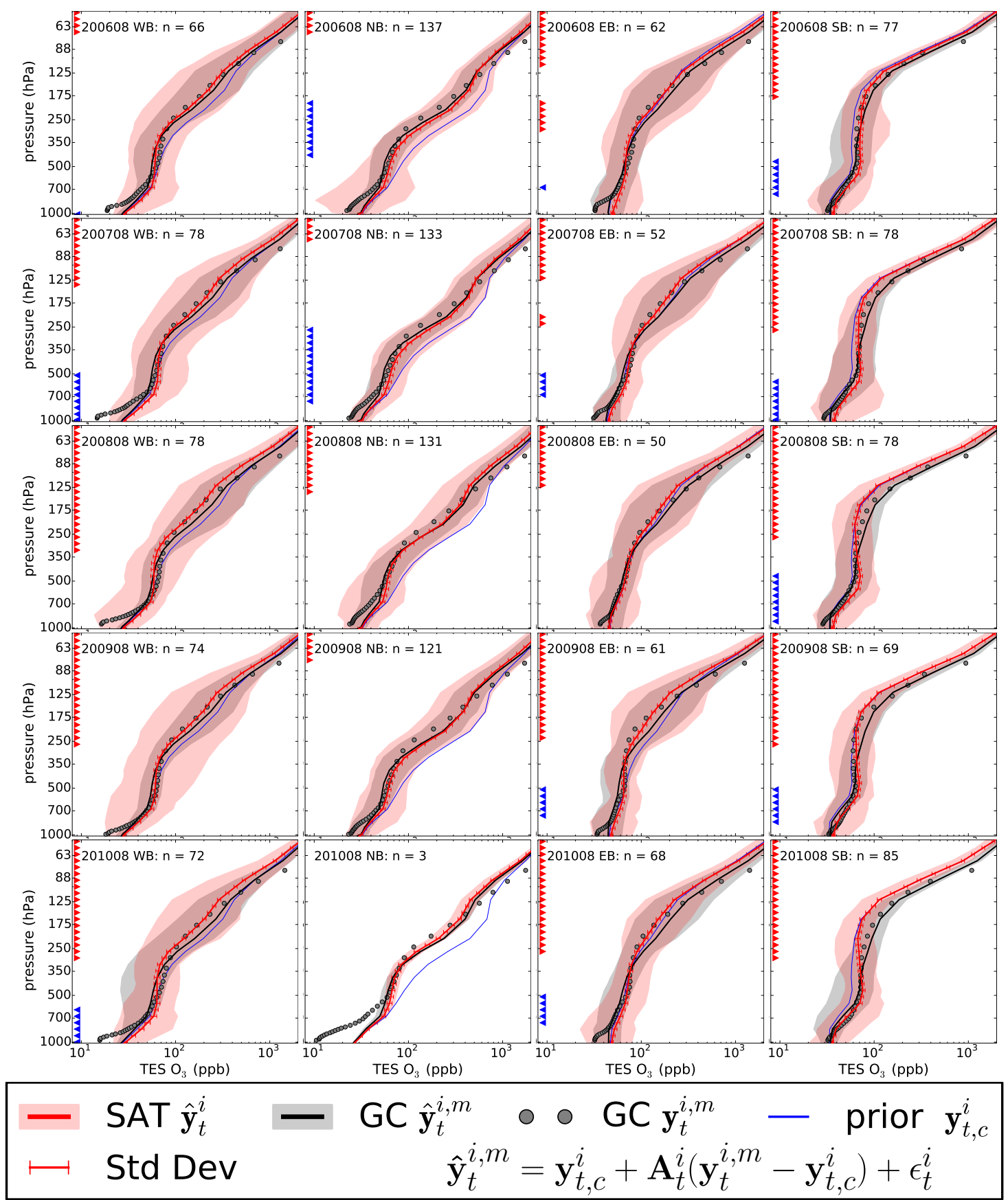

Fig. A2. Same as Fig. A1, but for August and includes year 2010. 

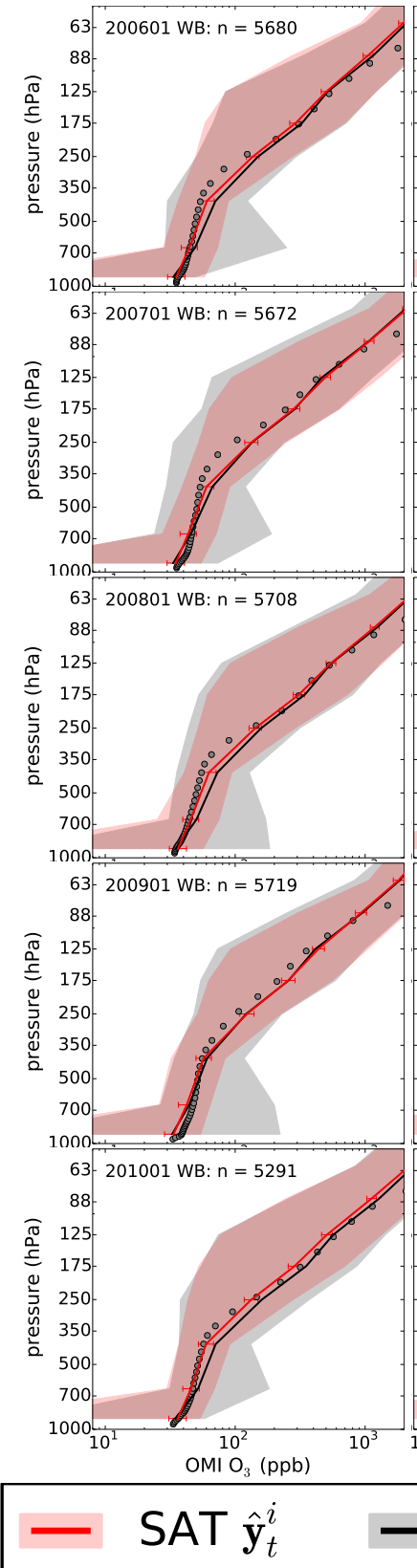

Std Dev

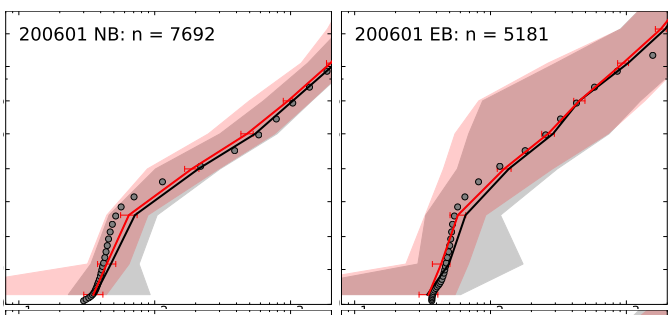

200701 NB: $n=7710$

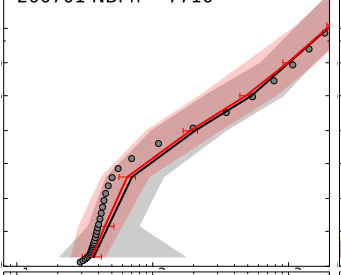

$200801 N B: n=7817$

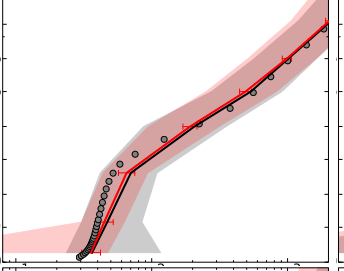

200901 NB: $n=7301$

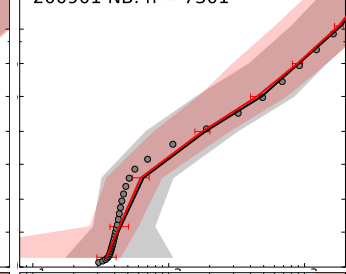

$201001 N B: n=6488$
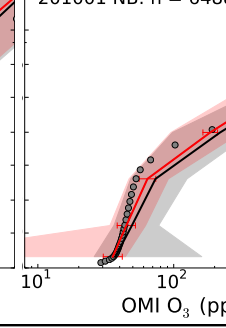

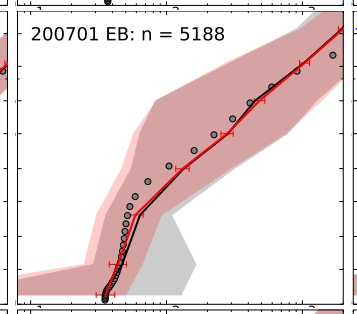

$200801 \mathrm{~EB}: \mathrm{n}=5249$

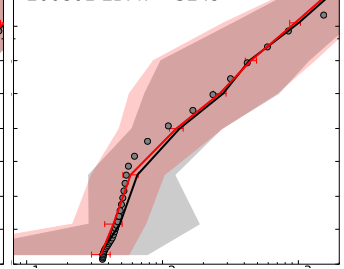

200901 EB: $n=5196$
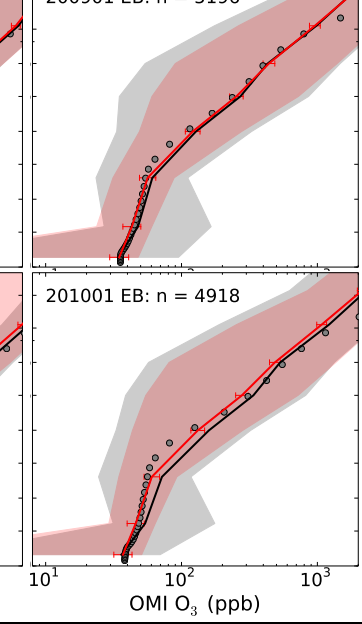

$\mathrm{OMI}_{3}^{10^{2}}(\mathrm{ppb})$
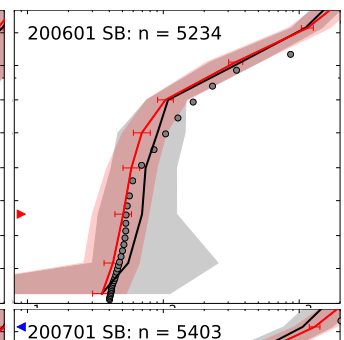

200701 SB: $n=5403$
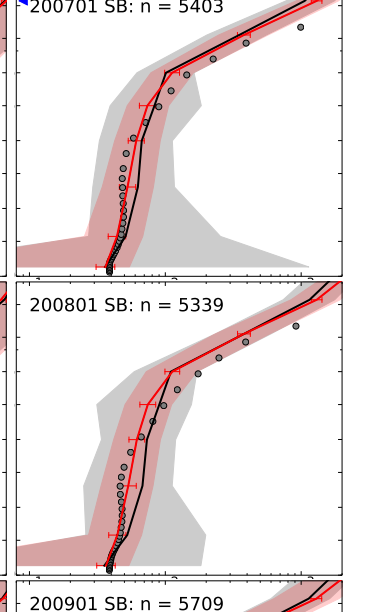

200901 SB: $n=5709$

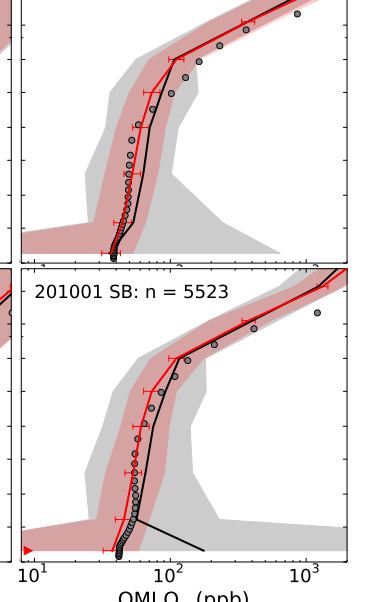
$\mathrm{OMI} \mathrm{O}_{3}(\mathrm{ppb})$

$$
\begin{array}{r}
\mathrm{GC} \hat{\mathbf{y}}_{t}^{i, m} \circ \circ \mathrm{GC} \mathbf{y}_{t}^{i, m}-\text { prior } \mathbf{y}_{t, c}^{i} \\
\hat{\mathbf{y}}_{t}^{i, m}=\mathbf{y}_{t, c}^{i}+\mathbf{A}_{t}^{i}\left(\mathbf{y}_{t}^{i, m}-\mathbf{y}_{t, c}^{i}\right)+\epsilon_{t}^{i}
\end{array}
$$

Fig. A3. Same as Fig. A1, but for OMI. 


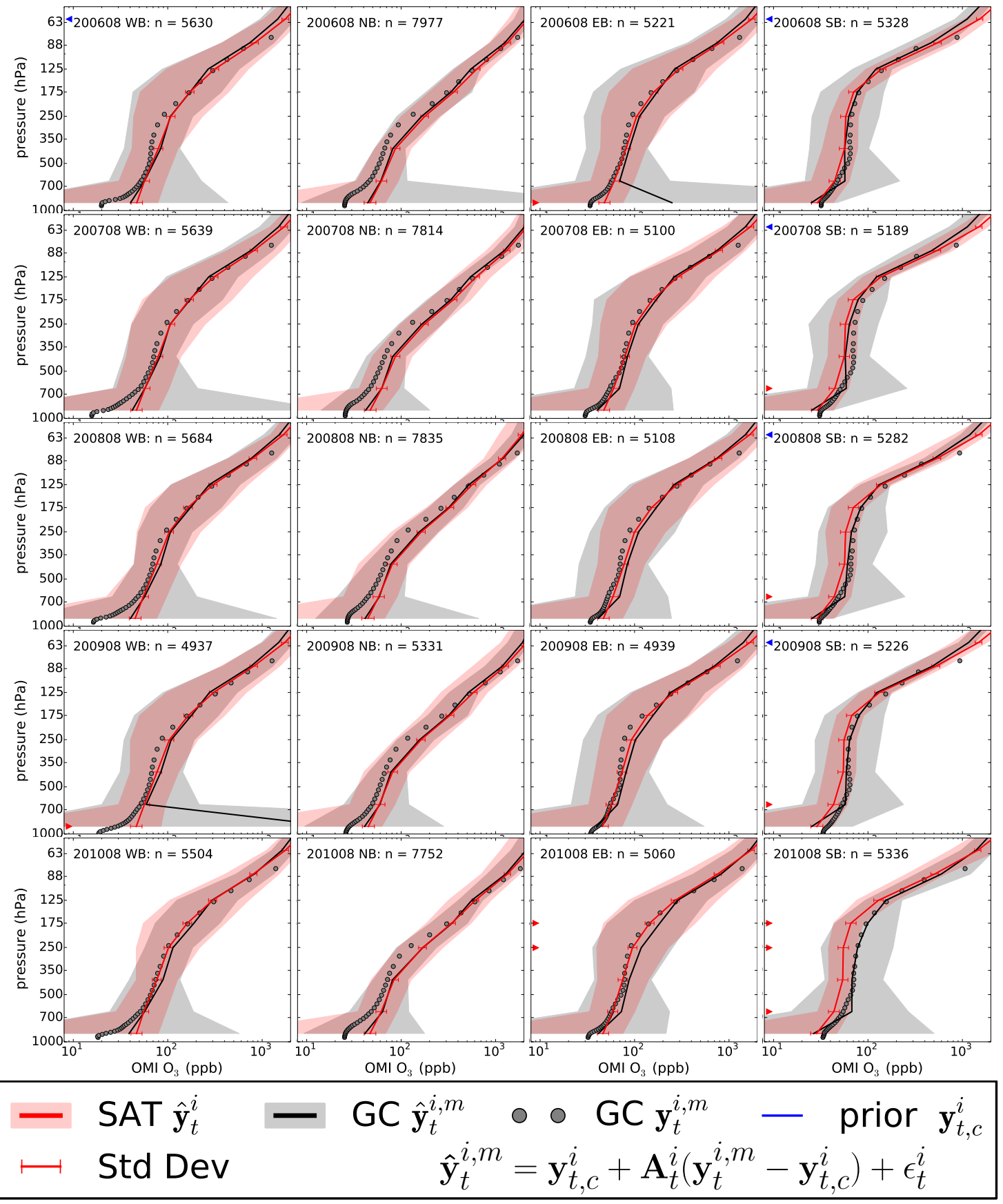

Fig. A4. Same as Fig. A2, but for OMI. 


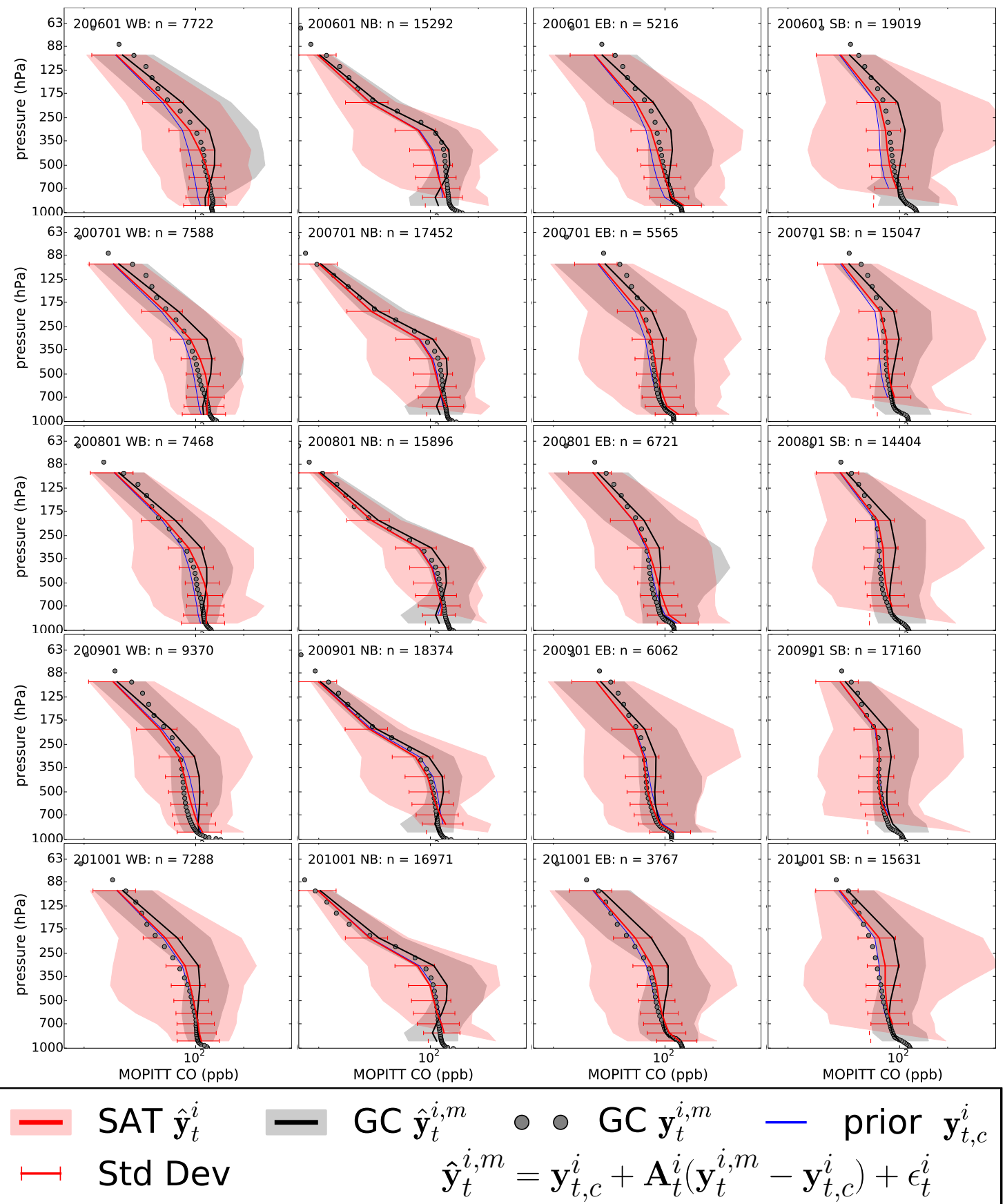

Fig. A5. Same as Fig. A1, but for MOPITT. 


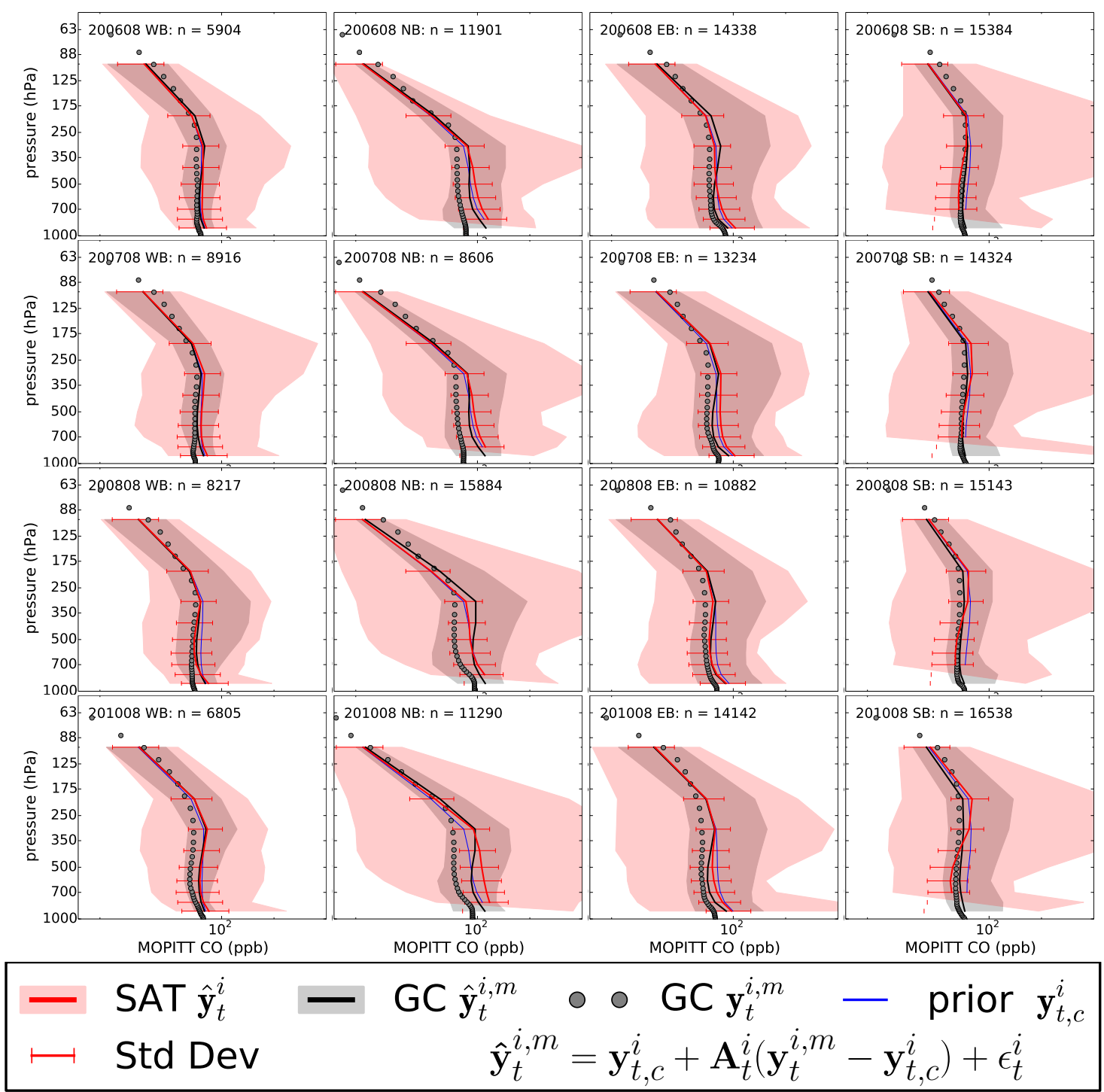

Fig. A6. Same as Fig. A2, but for MOPITT; does not have year 2009, and includes year 2010.

Table A1. Carbon Bond '05 (CB05) species mapping in the form CB05 Species, GEOS-Chem expression.

\begin{tabular}{|c|c|c|}
\hline $\mathrm{O}_{3}, \mathrm{O}_{\mathrm{x}}-\mathrm{NO}_{\mathrm{x}}$ & $\mathrm{PANX}, \mathrm{PPN}+\mathrm{PMN}$ & PAR, 3. * ACET \\
\hline $\mathrm{N}_{2} \mathrm{O}_{5}, \mathrm{~N}_{2} \mathrm{O}_{5}$ & OLE, $0.5 * 1 . / 2 . * 3 . * \mathrm{PRPE}$ & PAR, 4. * MEK \\
\hline $\mathrm{HNO}_{3}, \mathrm{HNO}_{3}$ & IOLE, $0.5 * 1 . / 4 * * 3 . * \mathrm{PRPE}$ & PAR, 1. * BENZ \\
\hline $\mathrm{PNA}, \mathrm{HNO}_{4}$ & TOL, TOLU & ALDX, RCHO \\
\hline $\mathrm{H}_{2} \mathrm{O}_{2}, \mathrm{H}_{2} \mathrm{O}_{2}$ & XYL, XYLE & ETH, ETH \\
\hline NTR, R4N2 & ISPD, MACR + MVK & $\mathrm{HO}_{2}, \mathrm{HO}_{2}$ \\
\hline $\mathrm{FORM}, \mathrm{CH}_{2} \mathrm{O}$ & $\mathrm{SO}_{2}, \mathrm{SO}_{2}$ & HONO, HONO \\
\hline ALD2, ALD2 & ETHA, $\mathrm{C}_{2} \mathrm{H}_{6}$ & MGLY, MGLY \\
\hline $\mathrm{CO}, \mathrm{CO}$ & BENZENE, BENZ & $\mathrm{NO}, \mathrm{NO}$ \\
\hline MEPX, MP & ISOP, ISOP & $\mathrm{NO}_{2}, \mathrm{NO}_{2}$ \\
\hline PAN, PAN & PAR, $1.5 * \mathrm{C}_{3} \mathrm{H}_{8}$ & $\mathrm{NO}_{3}, \mathrm{NO}_{3}$ \\
\hline TERP,ALPH + LIMO + ALCO & PAR, 4. * ALK4 & \\
\hline
\end{tabular}


Table A2. SAPRC07 species mapping in the form SAPRC07 Species, GEOS-Chem expression.

\begin{tabular}{|c|c|c|}
\hline ACETONE, ACET & MACR, MACR & $\mathrm{RNO}_{3}, \mathrm{R} 4 \mathrm{~N} 2$ \\
\hline ALK1, $\mathrm{C}_{2} \mathrm{H}_{6}$ & MAPAN, PMN & ROOH, ETP \\
\hline $\mathrm{ALK} 2, \mathrm{C}_{3} \mathrm{H}_{8}$ & MEK, MEK/3 & ROOH, IAP \\
\hline ALK3, ALK4/2 & $\mathrm{MEOH}, \mathrm{MOH}$ & ROOH, INPN \\
\hline ALK4, ALK4/4 & MGLY, MGLY & ROOH, ISNP \\
\hline ALK5, ALK4/4 & MVK, MVK & ROOH, MAOP \\
\hline BENZENE, BENZ & MXYL, XYLE/3 & ROOH, MRP \\
\hline $\mathrm{CCHO}, \mathrm{ALD} 2$ & $\mathrm{~N}_{2} \mathrm{O}_{5}, \mathrm{~N}_{2} \mathrm{O}_{5}$ & $\mathrm{ROOH}, \mathrm{PP}$ \\
\hline $\mathrm{CCOOH}, \mathrm{ACTA}$ & $\mathrm{NH}_{3}, \mathrm{NH}_{3}$ & ROOH, PRPN \\
\hline ССОООН, MAP & $\mathrm{NO}, \mathrm{NO}$ & $\mathrm{ROOH}, \mathrm{R} 4 \mathrm{P}$ \\
\hline $\mathrm{CO}, \mathrm{CO}$ & $\mathrm{NO}_{2}, \mathrm{NO}_{2}$ & ROOH, RA3P \\
\hline $\mathrm{COOH}, \mathrm{MP}$ & $\mathrm{NO}_{3}, \mathrm{NO}_{3}$ & $\mathrm{ROOH}, \mathrm{RB} 3 \mathrm{P}$ \\
\hline $\mathrm{HCHO}, \mathrm{CH}_{2} \mathrm{O}$ & $\mathrm{O}_{3}, \mathrm{O}_{\mathrm{x}}-\mathrm{NO}_{\mathrm{x}}$ & ROOH, RIP \\
\hline $\mathrm{HNO}_{3}, \mathrm{HNO}_{3}$ & OXYL, XYLE/3 & $\mathrm{ROOH}, \mathrm{RP}$ \\
\hline $\mathrm{HNO}_{4}, \mathrm{HNO}_{4}$ & PAN, PAN & ROOH, VRP \\
\hline $\mathrm{HO}_{2} \mathrm{H}, \mathrm{H}_{2} \mathrm{O}_{2}$ & PAN2, PPN & $\mathrm{SO}_{2}, \mathrm{SO}_{2}$ \\
\hline HOCCHO, GLYC & $\mathrm{PRD} 2, \mathrm{MEK} * 2 / 3$ & TERP,ALPH + LIMO + ALCO \\
\hline $\mathrm{HONO}, \mathrm{HNO}_{2}$ & PROPENE, PRPE & TOLUENE, TOLU \\
\hline \multirow[t]{2}{*}{ ISOPRENE, ISOP } & PXYL, XYLE/3 & \\
\hline & $\mathrm{RCHO}, \mathrm{RCHO}$ & \\
\hline
\end{tabular}

Table A3. CMAQ Aerosols version 6 (AE6) in the form AE6 Species, GEOS-Chem expression.

\begin{tabular}{|c|c|c|}
\hline AALJ, $0.05695 *$ DST 1 & ANO3J, $0.99 *$ NIT & ATIJ, $0.0028 *$ DST1 \\
\hline AALKJ, AALKJ & ANO3K, $0.0016^{*} \mathrm{DST} 2$ & ATOL1J, $0.04 *$ SOA5 \\
\hline ABNZ1J, $0.12 *$ SOA5 & ANO3K, $0.0016 *$ DST3 & ATOL2J, $0.04 *$ SOA5 \\
\hline ABNZ2J, $0.04 *$ SOA5 & ANO3K, $0.0016 *$ DST4 & ATOL3J, $0.29 *$ SOA5 \\
\hline ABNZ3J, $0.32 *$ SOA5 & ANO3K, NITs & ATRP1J, $0.33 *$ SOA 1 \\
\hline ACAJ, $0.0118 *$ SALA & AOLGAJ, AOLGAJ & ATRP1J, $0.33 *$ SOA2 \\
\hline ACAJ, $0.07940 *$ DST 1 & AOLGBJ, AOLGBJ & ATRP2J, $0.67 *$ SOA 1 \\
\hline ACLJ, $0.00945 *$ DST1 & AOTHRJ, $0.50219 *$ DST 1 & ATRP2J, $0.67 *$ SOA2 \\
\hline ACLJ, $0.5538 *$ SALA & APNCOMI, $0.4 * 0.001 *$ OCPI & AXYL1J, $0.03 *$ SOA5 \\
\hline ACLK, $0.01190 *$ DST2 & APNCOMI, $0.4 * 0.001 *$ OCPO & AXYL2J, $0.01 *$ SOA5 \\
\hline ACLK, $0.01190 *$ DST3 & APNCOMJ, $0.4 * 0.999 *$ OCPI & AXYL3J, $0.11 *$ SOA5 \\
\hline ACLK, $0.01190 *$ DST4 & APNCOMJ, $0.4 * 0.999 *$ OCPO & NH3, NH3 \\
\hline ACLK, $0.5538 *$ SALC & APNCOMJ, $0.0043 *$ DST1 & NUMACC, NUMACC \\
\hline ACORS, ACORS & APOCI, $0.001 *$ OCPI & NUMATKN, NUMATKN \\
\hline AECI, $0.001 *$ BCPI & APOCI, $0.001 *$ OCPO & NUMCOR, NUMCOR \\
\hline AECI, $0.001 * \mathrm{BCPO}$ & APOCJ, $0.999 *$ OCPI & SRFACC, SRFACC \\
\hline AECJ, $0.999 *$ BCPI & APOCJ, $0.999 *$ OCPO & SRFATKN, SRFATKN \\
\hline AECJ, $0.999 *$ ВCPO & APOCJ, $0.01075 *$ DST1 & SRFCOR, SRFCOR \\
\hline AFEJ, $0.03355 *$ DST 1 & ASEACAT, $0.3685 *$ SALC & SULF, SULF \\
\hline AISO1J, $0.75 *$ SOA 4 & ASIJ, $0.19435 *$ DST1 & SV_ALK, SV_ALK \\
\hline AISO2J, $0.25 *$ SOA 4 & ASO4I, $0.01 *$ SO 4 & SV_BNZ1, $0.06 *$ SOG5 \\
\hline AISO3J, AISO3J & ASO4J, $0.99 * \mathrm{SO} 4$ & SV_BNZ2, $0.23 *$ SOG5 \\
\hline AKJ, $0.0114 *$ SALA & ASO4J, $0.0225 *$ DST 1 & SV_ISO1, $0.75 *$ SOG4 \\
\hline AKJ, $0.03770 *$ DST 1 & ASO4J, $0.0776 *$ SALA & SV_ISO2, $0.25 *$ SOG4 \\
\hline AMGJ, $0.0368 *$ SALA & ASO4K, $0.0776 *$ SALC & SV_SQT, SOG3 \\
\hline AMNJ, $0.00115 *$ DST 1 & ASO4K, $0.02655 *$ DST2 & SV_TOL1, $0.23 *$ SOG5 \\
\hline ANAJ, $0.3086 *$ SALA & ASO4K, 0.02655 * DST3 & SV_TOL2, $0.23 *$ SOG5 \\
\hline ANAJ, $0.03935 *$ DST 1 & $\mathrm{ASO} 4 \mathrm{~K}, 0.02655 * \mathrm{DST} 4$ & SV_TRP1, $0.33 *$ SOG1 \\
\hline ANH4I, $0.01 * \mathrm{NH} 4$ & $\mathrm{ASO} 4 \mathrm{~K}, \mathrm{SO} 4 \mathrm{~s}$ & SV_TRP1, $0.33 *$ SOG 2 \\
\hline ANH4J, $0.00005 *$ DST 1 & ASOIL, $0.95995 *$ DST2 & SV_TRP2, $0.67 *$ SOG1 \\
\hline ANH4J, $0.99 * \mathrm{NH} 4$ & ASOIL, $0.95995 *$ DST3 & SV_TRP $2,0.67 *$ SOG 2 \\
\hline ANO3I, $0.01 *$ NIT & ASOIL, $0.95995 *$ DST4 & SV_XYL1, $0.19 *$ SOG5 \\
\hline ANO3J, $0.00020 *$ DST 1 & ASQTJ, SOA3 & SV_XYL2, $0.06 *$ SOG5 \\
\hline
\end{tabular}


Acknowledgements. Barron H. Henderson was supported in part by the Research Participation Program at the Environmental Protection Agency administered by the Oak Ridge Institute for Science and Education, and in part by startup funds from the University of Florida.

The United States Environmental Protection Agency (EPA) through its Office of Research and Development collaborated in the research described here. This paper has been subjected to the Agency's administrative review and approved for publication.

Edited by: R. Redler

\section{References}

Alexander, B.: Sulfate formation in sea-salt aerosols: constraints from oxygen isotopes, J. Geophys. Res., 110, D10307, doi:10.1029/2004JD005659, 2005.

Appel, K. W. and Gilliland, A. B.: Effects of vertical-layer structure and boundary conditions on CMAQ - v4.5 and v4.6 models, Chapel Hill, NC, available at: http://www.cmascenter. org/conference/2006/abstracts/appel_session4.pdf (last access: 23 August 2013), 2006.

Appel, K. W., Pouliot, G. A., Simon, H., Sarwar, G., Pye, H. O. T., Napelenok, S. L., Akhtar, F., and Roselle, S. J.: Evaluation of dust and trace metal estimates from the Community Multiscale Air Quality (CMAQ) model version 5.0, Geosci. Model Dev., 6, 883-899, doi:10.5194/gmd-6-883-2013, 2013.

Barna, M. G. and Knipping, E. M.: Insights from the BRAVO study on nesting global models to specify boundary conditions in regional air quality modeling simulations, Atmos. Environ., 40, Supplement 2, 574-582, doi:10.1016/j.atmosenv.2006.01.065, 2006.

Berdowski, J., Guicherit, R., Heij, B., and Dutch National Research Programme on Global Air Pollution and Climate Change: The Climate System, A. A. Balkema Publishers, Lisse, Exton, PA, 2001.

Binkowski, F. S. and Roselle, S. J.: Models-3 Community Multiscale Air Quality (CMAQ) model aerosol component 1. Model description, J. Geophys. Res. Atmos., 108, 4183, doi:10.1029/2001JD001409, 2003.

Bourqui, M. S., Yamamoto, A., Tarasick, D., Moran, M. D., Beaudoin, L.-P., Beres, I., Davies, J., Elford, A., Hocking, W., Osman, M., and Wilkinson, R.: A new global real-time Lagrangian diagnostic system for stratosphere-troposphere exchange: evaluation during a balloon sonde campaign in eastern Canada, Atmos. Chem. Phys., 12, 2661-2679, doi:10.5194/acp-12-26612012, 2012.

Bowman, K., Eldering, A., Fisher, B., Jacob, D., Jourdain, L., Kulawik, S. S., Luo, M., Monarrez, R., Osterman, G., Paradise, S., Payne, V., Poosti, S., Rischards, N., Rider, D., Shepard, D., Shephard, M., Vilnrotter, F., Worden, H., Worden, J., Yun, H., and Zhang, L.: Earth Observing System (EOS) Tropospheric Emission Spectrometer (TES) Level 2 (L2) Data User's Guide (Up to and including Version 5 data), 5.0 Edn., edited by: Herman, R. and Kulawik, S., available at: http://tes.jpl. nasa.gov/uploadedfiles/TES_L2_Data_Users_Guide-3.pdf (last access: 23 August 2013), 2011.

Carlton, A. G., Bhave, P. V., Napelenok, S. L., Edney, E. O., Sarwar, G., Pinder, R. W., Pouliot, G. A., and Houyoux, M.: Model representation of secondary organic aerosol in CMAQv4.7, Environ. Sci. Technol., 44, 8553-8560, doi:10.1021/es100636q, 2010.

Chung, S. H.: Global distribution and climate forcing of carbonaceous aerosols, J. Geophys. Res., 107, 4407, doi:10.1029/2001JD001397, 2002.

Cooper, O. R., Parrish, D. D., Stohl, A., Trainer, M., Nedelec, P., Thouret, V., Cammas, J. P., Oltmans, S. J., Johnson, B. J., Tarasick, D., Leblanc, T., McDermid, I. S., Jaffe, D., Gao, R., Stith, J., Ryerson, T., Aikin, K., Campos, T., Weinheimer, A., and Avery, M. A.: Increasing springtime ozone mixing ratios in the free troposphere over western North America, Nature, 463, 344-348, doi:10.1038/nature08708, 2010.

Cui, J., Sprenger, M., Staehelin, J., Siegrist, A., Kunz, M., Henne, S., and Steinbacher, M.: Impact of stratospheric intrusions and intercontinental transport on ozone at Jungfraujoch in 2005: comparison and validation of two Lagrangian approaches, Atmos. Chem. Phys., 9, 3371-3383, doi:10.5194/acp-9-33712009, 2009.

Deeter, M. N., Emmons, L. K., Francis, G. L., Edwards, D. P., Gille, J. C., Warner, J. X., Khattatov, B., Ziskin, D., Lamarque, J.-F., Ho, S.-P., Yudin, V., Attié, J.-L., Packman, D., Chen, J., Mao, D. and Drummond, J. R.: Operational carbon monoxide retrieval algorithm and selected results for the MOPITT instrument, J. Geophys. Res. Atmos., 108, 4399, doi:10.1029/2002JD003186, 2003.

Dentener, F., Keating, T. J., and Akimoto, H.: Hemispheric transport of air pollution. Part A: Ozone and Particulate Matter, Economic Commission For Europe United Nations, Geneva, 2010.

Environment Canada: National Pollutant Release Inventory, Environ. Can., available at: http://www.ec.gc.ca/inrp-npri/ (last access: 23 August 2013), 2013.

Fiore, A. M., Jacob, D. J., Bey, I., Yantosca, R. M., Field, B. D., Fusco, A. C., and Wilkinson, J. G.: Background ozone over the United States in summer: origin, trend, and contribution to pollution episodes, J. Geophys. Res.-Atmos., 107, ACH 11-1ACH 11-25, doi:10.1029/2001JD000982, 2002.

Fiore, A. M., Dentener, F. J., Wild, O., Cuvelier, C., Schultz, M. G., Hess, P., Textor, C., Schulz, M., Doherty, R. M., Horowitz, L. W., MacKenzie, I. A., Sanderson, M. G., Shindell, D. T., Stevenson, D. S., Szopa, S., Dingenen, R. V., Zeng, G., Atherton, C., Bergmann, D., Bey, I., Carmichael, G., Collins, W. J., Duncan, B. N., Faluvegi, G., Folberth, G., Gauss, M., Gong, S., Hauglustaine, D., Holloway, T., Isaksen, I. S. A., Jacob, D. J., Jonson, J. E., Kaminski, J. W., Keating, T. J., Lupu, A., Marmer, E., Montanaro, V., Park, R. J., Pitari, G., Pringle, K. J., Pyle, J. A., Schroeder, S., Vivanco, M. G., Wind, P., Wojcik, G., Wu, S., and Zuber, A.: Multimodel estimates of intercontinental source-receptor relationships for ozone pollution, J. Geophys. Res., 114, D04301, doi:10.1029/2008JD010816, 2009.

Foley, K. M., Roselle, S. J., Appel, K. W., Bhave, P. V., Pleim, J. E., Otte, T. L., Mathur, R., Sarwar, G., Young, J. O., Gilliam, R. C., Nolte, C. G., Kelly, J. T., Gilliland, A. B., and Bash, J. O.: Incremental testing of the Community Multiscale Air Quality (CMAQ) modeling system version 4.7, Geosci. Model Dev., 3, 205-226, doi:10.5194/gmd-3-205-2010, 2010.

Fu, J. S., Streets, D. G., Jang, C. J., Hao, J., He, K., Wang, L., and Zhang, Q.: Modeling Regional/Urban Ozone and Particu- 
late Matter in Beijing, China, J. Air Waste Manage., 59, 37-44, doi:10.3155/1047-3289.59.1.37, 2009.

Gégo, E., Gilliland, A., Godowitch, J., Rao, S. T., Porter, P. S., and Hogrefe, C.: Modeling analyses of the effects of changes in nitrogen oxides emissions from the electric power sector on ozone levels in the Eastern US, J. Air Waste Manage., 58, 580-588, doi:10.3155/1047-3289.58.4.580, 2008.

Godowitch, J. M., Gilliland, A. B., Draxler, R. R., and Rao, S. T.: Modeling assessment of point source $\mathrm{NO}_{\mathrm{x}}$ emission reductions on ozone air quality in the eastern United States, Atmos. Environ., 42, 87-100, doi:10.1016/j.atmosenv.2007.09.032, 2008.

Guenther, A. B., Jiang, X., Heald, C. L., Sakulyanontvittaya, T., Duhl, T., Emmons, L. K., and Wang, X.: The Model of Emissions of Gases and Aerosols from Nature version 2.1 (MEGAN2.1): an extended and updated framework for modeling biogenic emissions, Geosci. Model Dev., 5, 1471-1492, doi:10.5194/gmd-51471-2012, 2012.

Henze, D. K., Seinfeld, J. H., Ng, N. L., Kroll, J. H., Fu, T.-M., Jacob, D. J., and Heald, C. L.: Global modeling of secondary organic aerosol formation from aromatic hydrocarbons: highvs. low-yield pathways, Atmos. Chem. Phys., 8, 2405-2420, doi:10.5194/acp-8-2405-2008, 2008.

Hogrefe, C., Civerolo, K. L., Hao, W., Ku, J.-Y., Zalewsky, E. E., and Sistla, G.: Rethinking the assessment of photochemical modeling systems in air quality planning applications, J. Air Waste Manage., 58, 1086-1099, doi:10.3155/1047-3289.58.8.1086, 2008.

Jacobson, Z. M. and Turco, R. P.: SMVGEAR: a sparse-matrix, vectorized gear code for atmospheric models, Atmos. Environ., 28, 273-284, doi:10.1016/1352-2310(94)90102-3, 1994.

Jiménez, P., Parra, R., and Baldasano, J. M.: Influence of initial and boundary conditions for ozone modeling in very complex terrains: a case study in the northeastern Iberian Peninsula, Environ. Modell. Softw., 22, 1294-1306, doi:10.1016/j.envsoft.2006.08.004, 2007.

Krueger, A. J. and Minzner, R. A.: A mid-latitude ozone model for the 1976 US Standard Atmosphere, J. Geophys. Res., 81, 4477, doi:10.1029/JC081i024p04477, 1976.

Kuhns, H., Green, M., and Etyemezian, V.: Big Bend Regional Aerosol and Visibility Observational (BRAVO) Study Emissions Inventory, Desert Res. Inst., available at: http://acmg.seas. harvard.edu/geos/word_pdf_docs/BRAVOEI_Report_d2.pdf (last access: 23 August 2013), 2003.

Lacis, A. A., Wuebbles, D. J., and Logan, J. A.: Radiative forcing of climate by changes in the vertical distribution of ozone, J. Geophys. Res., 95, 9971-9981, doi:10.1029/JD095iD07p09971, 1990.

Lam, Y. F. and Fu, J. S.: A novel downscaling technique for the linkage of global and regional air quality modeling, Atmos. Chem. Phys., 9, 9169-9185, doi:10.5194/acp-9-9169-2009, 2009.

Lefohn, A. S., Wernli, H., Shadwick, D., Limbach, S., Oltmans, S. J., and Shapiro, M.: The importance of stratospherictropospheric transport in affecting surface ozone concentrations in the western and northern tier of the United States, Atmos. Environ., 45, 4845-4857, doi:10.1016/j.atmosenv.2011.06.014, 2011

Liao, H., Henze, D. K., Seinfeld, J. H., Wu, S., and Mickley, L. J.: Biogenic secondary organic aerosol over the United States: com- parison of climatological simulations with observations, J. Geophys. Res., 112, D06201, doi:10.1029/2006JD007813, 2007.

Lin, C., Jacob, D., Munger, J., and Fiore, A.: Increasing background ozone in surface air over the United States, Geophys. Res. Lett., 27, 3465-3468, doi:10.1029/2000GL011762, 2000.

Lin, H., Mathur, R., McKeen, S. A., and McQueen, J.: Application of Potential Vorticity in a comprehensive air quality forecast model for Ozone, available at: https://ams.confex.com/ams/ 88Annual/techprogram/paper_132967.htm (last access: $23 \mathrm{Au}-$ gust 2013), 2008.

Lin, M., Fiore, A. M., Horowitz, L. W., Cooper, O. R., Naik, V., Holloway, J., Johnson, B. J., Middlebrook, A. M., Oltmans, S. J., Pollack, I. B., Ryerson, T. B., Warner, J. X., Wiedinmyer, C., Wilson, J., and Wyman, B.: Transport of Asian ozone pollution into surface air over the Western United States in spring, J. Geophys. Res., 117, D00V07, doi:10.1029/2011JD016961, 2012.

Logan, J. A., Megretskaia, I. A., Miller, A. J., Tiao, G. C., Choi, D., Zhang, L., Stolarski, R. S., Labow, G. J., Hollandsworth, S. M., Bodeker, G. E., Claude, H., Muer, D. D., Kerr, J. B., Tarasick, D. W., Oltmans, S. J., Johnson, B., Schmidlin, F., Staehelin, J., Viatte, P., and Uchino, O.: Trends in the vertical distribution of ozone: a comparison of two analyses of ozonesonde data, J. Geophys. Res., 104, 26373-26399, doi:10.1029/1999JD900300, 1999.

Mao, J., Paulot, F., Jacob, D., Cohen, R., Crounse, J., Wennberg, P., Keller, C., Hudman, R., Barkley, M., and Horowitz, L.: Ozone and Organic Nitrates over the Eastern US: Sensitivity to Isoprene Chemistry, 2013.

Molod, A., Takacs, L., Suarez, M., Bacmeister, J., Song, I.-S., and Eichmann, A.: The GEOS-5 Atmospheric General Circulation Model: Mean Climate and Development from MERRA to Fortuna, 2012.

Napelenok, S. L., Cohan, D. S., Odman, M. T., and Tonse, S.: Extension and evaluation of sensitivity analysis capabilities in a photochemical model, Environ. Modell. Softw., 23, 994-999, doi:10.1016/j.envsoft.2007.11.004, 2008.

Napelenok, S. L., Foley, K. M., Kang, D., Mathur, R., Pierce, T., and Rao, S. T.: Dynamic evaluation of regional air quality model's response to emission reductions in the presence of uncertain emission inventories, Atmos. Environ., 45, 4091-4098, doi:10.1016/j.atmosenv.2011.03.030, 2011.

Nassar, R., Logan, J. A., Worden, H. M., Megretskaia, I. A., Bowman, K. W., Osterman, G. B., Thompson, A. M., Tarasick, D. W., Austin, S., Claude, H., Dubey, M. K., Hocking, W. K., Johnson, B. J., Joseph, E., Merrill, J., Morris, G. A., Newchurch, M., Oltmans, S. J., Posny, F., Schmidlin, F. J., Vömel, H., Whiteman, D. N., and Witte, J. C.: Validation of Tropospheric Emission Spectrometer (TES) nadir ozone profiles using ozonesonde measurements, J. Geophys. Res., 113, 17, doi:10.1029/2007JD008819, 2008.

Nghiem, L. H. and Oanh, N. T. K.: Evaluation of the Mesoscale Meteorological Model (MM5)-Community Multi-Scale Air Quality Model (CMAQ) performance in hindcast and forecast of ground-level ozone, J. Air Waste Manage., 58, 1341-1350, doi:10.3155/1047-3289.58.10.1341, 2008.

Ohara, T., Akimoto, H., Kurokawa, J., Horii, N., Yamaji, K., Yan, X. and Hayasaka, T.: An Asian emission inventory of anthropogenic emission sources for the period 1980-2020, Atmos. 
Chem. Phys., 7(16), 4419-4444, doi:10.5194/acp-7-4419-2007, 2007.

Oltmans, S. J., Lefohn, A. S., Harris, J. M., Galbally, I., Scheel, H. E., Bodeker, G., Brunke, E., Claude, H., Tarasick, D., Johnson, B. J., Simmonds, P., Shadwick, D., Anlauf, K., Hayden, K., Schmidlin, F., Fujimoto, T., Akagi, K., Meyer, C., Nichol, S., Davies, J., Redondas, A., and Cuevas, E.: Long-term changes in tropospheric ozone, Atmos. Environ., 40, 3156-3173, doi:10.1016/j.atmosenv.2006.01.029, 2006.

Oltmans, S. J., Lefohn, A. S., Harris, J. M., Tarasick, D. W., Thompson, A. M., Wernli, H., Johnson, B. J., Novelli, P. C., Montzka, S. A., Ray, J. D., Patrick, L. C., Sweeney, C., Jefferson, A., Dann, T., Davies, J., Shapiro, M., and Holben, B. N.: Enhanced ozone over western North America from biomass burning in Eurasia during April 2008 as seen in surface and profile observations, Atmos. Environ., 44, 4497-4509, doi:10.1016/j.atmosenv.2010.07.004, 2010.

Oreskes, N., Shrader-Frechette, K., and Belitz, K.: Verification, validation, and confirmation of numerical models in the Earth sciences, Science, 263, 641-646, doi:10.1126/science.263.5147.641, 1994.

Ott, L. E., Pickering, K. E., Stenchikov, G. L., Allen, D. J., Decaria, A. J., Ridley, B., Lin, R.-F., Lang, S., and Tao, W.$\mathrm{K}$.: Production of lightning $\mathrm{NO}_{\mathrm{x}}$ and its vertical distribution calculated from three-dimensional cloud-scale chemical transport model simulations, J. Geophys. Res., 115, D04301, doi:10.1029/2009JD011880, 2010.

Otte, T. L. and Pleim, J. E.: The Meteorology-Chemistry Interface Processor (MCIP) for the CMAQ modeling system: updates through MCIPv3.4.1, Geosci. Model Dev., 3, 243-256, doi:10.5194/gmd-3-243-2010, 2010.

Park, R. J.: Sources of carbonaceous aerosols over the United States and implications for natural visibility, J. Geophys. Res., 108, 4355, doi:10.1029/2002JD003190, 2003.

Park, R. J., Jacob, D. J., Field, B. D., Yantosca, R. M., and Chin, M.: Natural and transboundary pollution influences on sulfate-nitrate-ammonium aerosols in the United States: Implications for policy, J. Geophys. Res., 109, D15204, doi:10.1029/2003JD004473, 2004.

Pickering, K. E., Wang, Y., Tao, W.-K., Price, C., and Müller, J.-F.: Vertical distributions of lightning $\mathrm{NO}_{\mathrm{x}}$ for use in regional and global chemical transport models, J. Geophys. Res., 103, 3120331216, doi:10.1029/98JD02651, 1998.

Price, C. and Rind, D.: A simple lightning parameterization for calculating global lightning distributions, J. Geophys. Res.-Atmos., 97, 9919-9933, doi:10.1029/92JD00719, 1992.

Pye, H. O. T. and Napelenok, S. L.: Chemical mapping of GEOSChem to CMAQv5.0, available at: http://wiki.seas.harvard.edu/ geos-chem/index.php/GEOS-Chem_to_CMAQv5.0, last access 24 July 2013.

Pye, H. O. T., Liao, H., Wu, S., Mickley, L. J., Jacob, D. J., Henze, D. K., and Seinfeld, J. H.: Effect of changes in climate and emissions on future sulfate-nitrate-ammonium aerosol levels in the United States, J. Geophys. Res.-Atmos., 114, D01205, doi:10.1029/2008JD010701, 2009.

Reidmiller, D. R., Fiore, A. M., Jaffe, D. A., Bergmann, D., Cuvelier, C., Dentener, F. J., Duncan, B. N., Folberth, G., Gauss, M., Gong, S., Hess, P., Jonson, J. E., Keating, T., Lupu, A., Marmer, E., Park, R., Schultz, M. G., Shindell, D. T., Szopa, S.,
Vivanco, M. G., Wild, O., and Zuber, A.: The influence of foreign vs. North American emissions on surface ozone in the US, Atmos. Chem. Phys., 9, 5027-5042, doi:10.5194/acp-9-5027-2009, 2009.

Rienecker, M. M., Suarez, M. J., Gelaro, R., Todling, R., Bacmeister, J., Liu, E., Bosilovich, M. G., Schubert, S. D., Takacs, L., Kim, G.-K., Bloom, S., Chen, J., Collins, D., Conaty, A., da Silva, A., Gu, W., Joiner, J., Koster, R. D., Lucchesi, R., Molod, A., Owens, T., Pawson, S., Pegion, P., Redder, C. R., Reichle, R., Robertson, F. R., Ruddick, A. G., Sienkiewicz, M., and Woollen, J.: MERRA: NASA's Modern-Era Retrospective Analysis for Research and Applications, J. Climate, 24, 3624-3648, doi:10.1175/JCLI-D-11-00015.1, 2011.

Schichtel, B. A., Gebhart, K. A., Malm, W. C., Barna, M. G., Pitchford, M. L., Knipping, E. M., and Tombach, I. H.: Reconciliation and interpretation of Big Bend National Park particulate sulfur source apportionment: results from the Big Bend regional aerosol and visibility observational study - Part I, J. Air Waste Manage. 55, 1709-1725, doi:10.1080/10473289.2005.10464769, 2005.

Smyth, S. C., Jiang, W., Roth, H., Moran, M. D., Makar, P. A., Yang, F., Bouchet, V. S., and Landry, H.: A comparative performance evaluation of the AURAMS and CMAQ airquality modelling systems, Atmos. Environ., 43, 1059-1070, doi:10.1016/j.atmosenv.2008.11.027, 2009.

Song, C.-K., Byun, D. W., Pierce, R. B., Alsaadi, J. A., Schaack, T. K., and Vukovich, F.: Downscale linkage of global model output for regional chemical transport modeling: method and general performance, J. Geophys. Res., 113, D08308, doi:10.1029/2007JD008951, 2008.

Streets, D. G., Bond, T. C., Carmichael, G. R., Fernandes, S. D., Fu, Q., He, D., Kilmont, Z., Nelson, S. M., Tsai, N. Y., Wang, M. Q., Woo, J.-H., and Yarber, K. F.: An inventory of gaseous and primary aerosol emissions in Asia in the year 2000, J. Geophys. Res., 108, 8809, doi:10.1029/2002JD003093, 2003.

Streets, D. G., Zhang, Q., Wang, L., He, K., Hao, J., Wu, Y., Tang, Y., and Carmichael, G. R.: Revisiting China's CO emissions after the Transport and Chemical Evolution over the Pacific (TRACE-P) mission: synthesis of inventories, atmospheric modeling, and observations, J. Geophys. Res., 111, D14306, doi:10.1029/2006JD007118, 2006.

US EPA: National Emissions Inventory (NEI) Air Pollutant Emissions Trends Data, available at: http://www.epa.gov/ttnchie1/ trends/, last access 24 July 2013.

Valari, M., Menut, L., and Chatignoux, E.: Using a chemistry transport model to account for the spatial variability of exposure concentrations in epidemiologic air pollution studies, J. Air Waste Manage., 61, 164-179, doi:10.3155/1047-3289.61.2.164, 2011.

van der Werf, G. R., Randerson, J. T., Giglio, L., Collatz, G. J., Kasibhatla, P. S., and Arellano Jr., A. F.: Interannual variability in global biomass burning emissions from 1997 to 2004, Atmos. Chem. Phys., 6, 3423-3441, doi:10.5194/acp-6-3423-2006, 2006.

Vestreng, V. and Klein, H.: Emission data reported to UNECE/EMEP: quality assurance and trend analysis \& presentation of WebDab, MSC-W Status Rep 2002, available at: http:// emep.int/publ/reports/2002/mscw_note_1_2002.pdf (last access: 23 August 2013), 2002. 
Wang, Y., Logan, J. A., and Jacob, D. J.: Global simulation of tropospheric $\mathrm{O}_{3}-\mathrm{NO}_{\mathrm{x}}-$ hydrocarbon chemistry: 2. Model evaluation and global ozone budget, J. Geophys. Res., 103, 10727, doi:10.1029/98JD00157, 1998.

Warneck, P. and Williams, J.: The Atmospheric Chemist's Companion: Numerical Data for Use in the Atmospheric Sciences, 2012th Edn., Springer, 2012.

Worden, H. M., Logan, J. A., Worden, J. R., Beer, R., Bowman, K., Clough, S. A., Eldering, A., Fisher, B. M., Gunson, M. R., Herman, R. L., Kulawik, S. S., Lampel, M. C., Luo, M., Megretskaia, I. A., Osterman, G. B., and Shephard, M. W.: Comparisons of Tropospheric Emission Spectrometer (TES) ozone profiles to ozonesondes: methods and initial results, J. Geophys. Res., 112, D03309, doi:10.1029/2006JD007258, 2007.
Yantosca, R. M., Long, M. S., Payer, M., and Cooper, M.: GEOS-Chem v9-01-03 Online User's Guide, available at: http: //acmg.seas.harvard.edu/geos/doc/man/ (last access: 22 December 2012), 2012.

Yienger, J. J. and Levy, H.: Empirical model of global soilbiogenic $\mathrm{NO}_{\mathrm{x}}$ emissions, J. Geophys. Res., 100, 11447, doi:10.1029/95JD00370, 1995.

Zhang, Y., Pun, B., Wu, S.-Y., Vijayaraghavan, K., and Seigneur, C.: Application and evaluation of two air quality models for particulate matter for a Southeastern US episode, J. Air Waste Manage., 54, 1478-1493, doi:10.1080/10473289.2004.10471012, 2004. 